\title{
Changes in body perception caused by mental illness on the basis of Great Thoughts of Nervous Patient by Daniel Paul Schreber
}

\author{
Zmiany w postrzeganiu ciała wywołane chorobą psychiczną na podstawie \\ „Wielkich myśli pacjenta nerwowego” Daniela Paula Schrebera.
}

\author{
Wojciech Lipski BCDF
}

Speech Therapy and Applied Linguistics Department, UMCS, Lublin, Poland

\begin{abstract}
The article presents a study on delusory changes in perceiving one's own body in a patient with mental illness. The story of Daniel Paul Schreber is an example of strongly experienced delusions, which, in the described form are contemporarily attributed to schizophrenia. This story, coming from over one hundred years ago, is still vivid, and actualizes the image of mental illness and suffering connected with it in the thoughts of the reader. The author presents these characteristics focusing mainly on the symptoms of dysmorphognosia or dysmorphophobia, which became an important element of delusional constructs. He describes the nature of the experienced symptoms in detail, documenting them with extensive quotations from „Diary of a mental patient” written by such patient. The study of mental illness presented in the paper reveals the meanders of distorted psyche and some changes that are happening in it under the influence of delusions. It is a study undertaking the issue of describing and understanding the symptoms of mental disorders.
\end{abstract}

Keywords: dysmorphophobia, dysmorphognosia, schizophrenia, delusions, diaries, Daniel Paul Schreber

\begin{abstract}
Streszczenie
Artykuł przedstawia studium na temat urojeniowych zmian w postrzeganiu własnego ciała u pacjenta z chorobą psychiczną. Historia Daniela Paula Schrebera jest przykładem silnie przeżywanych urojeń, które w opisywanym kształcie współcześnie przypisuje się schizofrenii. Ta opowieść z przed przeszło stu lat jest wciąż żywa i aktualizuje w myślach czytelnika obraz choroby psychicznej i związanego z nią cierpienia. Autor przedstawia tę charakterystykę, skupiając się przede wszystkim na objawach dysmorfognozji czy dysmorfofobii, które stały się ważnym elementem urojeniowych konstrukcji. Opisuje dokładnie charakter przeżywanych objawów dokumentując je obszernymi cytatami z „Pamiętników nerwowo chorego” napisanych ręką pacjenta. Przedstawione w pracy studium choroby psychicznej odkrywa meandry zaburzonej psychiki i zmiany, jakie się w niej dokonują pod wpływem urojeń. To studium podejmujące problem opisu i zrozumienia objawów zaburzeń psychicznych.
\end{abstract}

Słowa kluczowe: dysmorfofobia, dysmorfognozja, schizofrenia, urojenia, pamiętniki, Daniel Paul Schreber

In the presented article I would like to wonder about the relationship between body and mind in the situation of a person with mental disorders. The issue I address here will concern changes in perceiving own body, which occurred in Daniel Paul Schreber as an effect of his mental illness. In order to carefully look at the posed problem, first a short history of that man's life should be presented. D.P. Schreber was born on 25th day of July, 1842 in Leipzig, Germany. His family had high status, mainly because his father, Daniel Gottlob Moritz Schreber, was a well-known and respected orthopedist. D.P. Schreber had a three years older brother, Gustav, a two year older sister, Anna, a four years younger sister, Sidonia and six years younger sister- Klara. His father was the head of the family, his mother-Paulina, had remained in his shadow until the accident, when Moritz was hit on the head with a ladder. That event changed Schreber's father. Since then, he started having depressive states and obsessive thoughts with aggressive contents. Not only did Schreber's father have mental problems, but also his elder brother, Gustav, suffered from depression. He headed the family after their father's death. He could not stand the pressure and committed suicide at the age of 38 years. In 1877 it was Daniel Paul who started taking over the duties and pressure that accompanied them. A year after his brother's suicidal death, D.P. Schreber married Sabine Behr, and afterwards, the first 
symptoms of his neurotic disorders occurred. A young and clever lawyer energetically got involved in local government activities. The couple tried to have children, however Daniel Paul's wife had two miscarriages. In autumn 1884 he was a candidate to Reichstag and, in spite of the fact that he was one of the favorites, he was not elected. This failure hurt Paul. He started to undergo treatment at Dr Richter's spa. However, the hydrotherapy and pharmacotherapy of that time turned out to be ineffective. Daniel Paul suffered from insomnia, felt anxiety, had suicidal thoughts and was agitated. It was only Prof. Flechsig who helped Schreber. He worked in the University Psychiatric Clinic in Leipzig, from where, on the 1st day of June, 1885, Schreber was released with a sense of being totally cured. In the subsequent years attempts at having an offspring by the Schrebers were still ineffective, but Daniel's professional career flourished. In June 1893 Schreber received the news about appointing him to the post in the Higher National Court, and in October the same year he received the post of the President of Senate. On the 23rd day of November, he consulted Prof. Flechsig with diagnosis of depression, accompanied by suicidal thoughts. For the second time Schreber was admitted to the University Psychiatric Clinic in Leipzig. In Autumn 1894 he was incapacitated. He was moved from Leipzig to the treatment institution in Lindenhof for two weeks, and then to Sonnenstein. From 1897, Paul started to work on his diaries and was writing first applications for discharge from hospital. This is how Daniel Paul's fight for regaining freedom started. It ended with the judgment of the 14th day of July, 1902, passed by the Higher National Court, on cancellation of guardianship, and on the 20th day of December, Schreber was released from that institutions. After the author's endeavors, in 1903, his diaries came out in print. They were entitled "Great Thoughts of a Mental Patient”. At that time Schreber's state could be defined as good. However, that was not the end of his mental problems. The third episode of his disease broke out in1907. The direct cause of its recurrence was Schreder's wife's apoplexy attack, which took place on the 14th day of November. On November 27th Schreber was taken to Leipzig-Dösen institution. He died psychosis on the 14th day of April 1911.

As it is shown by chronology, the events described in the diaries concern the time from before 1903. In his work the author focused on the period from 1893 to 1902, when he experienced the first recurrence of his illness. Schreber's diaries did not turn out to be an insignificant publication, a result of a creative act of the author's sick mind. Already since the moment they appeared, they have been very popular among the psychiatrists of that time. Separate studies on them where written by S. Freud and C.G. Jung. Until nowadays they have been an object of attention for persons interested in delusions. They have been translated and published all over the world. Zvi Lothane called „The Diaries" the most wonderful book that has ever been written by a person staying in hospital. In his opinion „it is a work of art, a philosophical epic poem in prose in the mode of Goethe's Faustus" [1].

After this short introduction outlining the silhouette of D.P. Schreber, I would like to pass on to present and analyze the problem posed in the title of this article. The disease, distorting the reception of external and internal reality, generated in the author of "The Diaries" the sense of transformations taking place in his physicality. With its development, in the patient's opinion, transformation of his own body took place. At the beginning of the recurrence of his illness, Schreber had the symptoms of hypochondria. The patient noticed that his body underwent emaciation. He does not mention that the reason for that was refusing to eat at that time. Schreber does not disclose the direct reason for refusing to eat. The Diaries do not contain information about his delusions connected with food occurring at that time. The patient writes about them in the context of later events. Schreber started to believe that as a man chosen by God he was to undergo the process of „de-masculinization” and save the world through the birth of a new generation of people that will replace the one that had undergone destruction. Sigmund Freud, in his study devoted to Schreber posed the thesis that "de-masculinization" stood for castration that Schreber started to desire subconsciously. According to the creator of psychoanalysis, Schreber fantasized erotically about giving himself to his physician from Leipzig - Prof. Flechsig. It was to be a feminine (homosexually passive) wishful fantasy. Schreber' s personality resisted to it, which induced the delusion of persecution, where the desired one became the persecutor, and the contents of the fantasy became the contents of persecution [2]. This way of Freud's thinking coincided with his theory of the origin of paranoia, which was always to result from delusions of persecution caused by homosexual desires. Regardless of Freud's explanations on the origin of Schreber's ideas about his transformation into a woman, I must say that this idea was the totem for the patient, and it became the purpose of his life. That totem was to prove his sanctity and exceptionality, at the same time being a proof of God's existence for Schreder, God who appointed him to be the savior. The thought of being transformed into a woman was preceded by the idea of a sexual submission, which descended upon the patient during sleep or after he had woken up (the author of the diaries is unable to specify that in detail himself):

... a few times in the little hours, still lying in bed (I don't know if it was half-sleep or when awake), I had an impression that moved me to the highest degree, when later, already fully awake, I was thinking about it. It was an idea that in fact it must be a really beautiful feeling to be 
a woman surrendering during a sexual intercourse [3].

This idea became the beginnig of delusions developing in the mind of the patient. As the disease progressed, they started to develop into very elaborate structures. Schreder started to include the phenomenon of "de-masculinization” into a set of miracles affecting his body. He described that process in the following way:

According to the order of the world, these miracles seemed the greatest that seemed to be somehow connected with the de-masculinization, which was to be performed on my body. That group of miracles included especially different transformations of my sexual organs, sporadic cases occurring (especially in bed), as the forecast of the actual retraction of the penis, more frequently though- if mostly impure rays participated in that process - as its softening, close to its almost total dissolution; next, pulling out the facial hair, especially moustache, with the use of magic, finally - change of the whole figure (reduction of body size), probably involving concentration of spinal vertebrae and perhaps also the bone substance of thighs. (...) I myself have an impression that my body has diminished by some six to eight centimeters, that is, it has approached feminine size [3].

In Schreber's way of thinking, transformation into a woman was to be subordinated to the mission that God designed for him in the earth. Schreber believed that he was predestined to save the world, as he was to be the creator of new people when the present population of the earth perishes. In his diaries Schreber compares himself to Christ, calls himself the wandering Jew, who, in his delusions, represents the savior of the world. In Schreber's opinion he was not the first one in history who was designed to be transformed into a woman. The biblical Noah after the deluge was also to undergo the process of "demasculinization", whereas Romulus and Remus were born by a man transformed into a woman:

Something similar to the conception of Jesus Christ by the immaculate virgin - that is the one who has never had a carnal intercourse with a man - took place in my own body. On two separate occasions (when I was still at Flechsig's) I had, though slightly faultily developed - a female sexual organ, and I felt vibrations in my body that correspond to the first movements of a human embryo. For by God's miracle the appropriate God's nerves similar to man's semen, were thrown into my body, so fertilization took place [3].

Schreber was to undergo "de-masculinization”, because God started to contact him with the use of „rays-nerves”:

According to my judgment for the order of the world the tendency according to which in certain circumstances the "de-masculinization" (transformation into a woman) must take place, of a man („who sees ghosts"), who entered into a no more breakable contact with god's nerves (rays) [3].

Schreber, in spite of sentences he repeated to himself many times: „do not think about the specific parts of the body" (p. 140) was unable to overcome the anancastic thoughts. He was constantly focused on his body and felt changes taking place in it, i.e. that his male body is being transformed into a female one. Incessantly, he had an impression that "female nerves of pleasure" were present in it. To resemble a woman more, he had his moustache shaven off, started to strip to the waist and put women's jewelry on.

The voices that Schreber heard repeated to him the command to "remove his shoes", which in "the language of souls" (as he defined his auditory hallucinations) is what refers to "de-masculinization". The sense of having a female body started to occur in Schreber first on the arms and hands, then it spread to legs, chest, buttocks and remaining parts of the body. The patient believed that his transformation resulted from predestination:

...I became aware without any doubts that the order of the world definitely requires de-masculinization, whether I personally like it, or not, and that, reasonably, I am left with nothing else than reconciliation with the thought of transforming into a woman [3].

A natural consequence of de-masculinization was to be fertilization, which was to be performed by „divine rays”. New human race was to be born of the patient's female body. Although the voices called that transformation into a woman would be a disgrace and cause of shame for him, Schreber was convinced about the need to sacrifice his manhood. He believed that humiliation he would experience through "demasculinization" would be atoned with saving the world. Thinking of being transformed into a woman with time became the patient's obsession. He was unable to imagine himself playing the piano, standing in front of a mirror, lying in bed, or leaning to get something without having breasts and female sexual organs. In Schreber's opinion, changes in his body were distinct enough to be noticed by any person being in contact with him.

During the intercourse my breasts seem to be quite full female breasts; this phenomenon can be noticed with anybody who wants to watch me.(...) anybody who would see me standing in front of the mirror with bare upper part of the body (even more so, if the illusion was supported by same feminine piece of jewelry), unquestionably, he would have an impression that he is looking at the upper part of a female body [3].

In connection with the court case for cancellation of incapacitation Schreber demanded being examined by a physician, who would substantiate his transformation into a woman and deny ascribing the name of hallucination to that transformation 
According to Zvi Lothane, Schreber's ideas about transformation into a woman were of messianic origin. The patient referred not only to the birth of Jesus, but also to the creation of man, described in the Book of Genesis. In his view, God, who created the world, had both sexes, and Adam, as the first man, was created as a hermaphrodite being [1].

Schreber was permanently submerged in delusions. He hallucinated most of the time. „Nerves-rays” affected him incessantly. He believed that most of the rays came from God, or, most specifically: from gods, because Schreber remarks that there are two gods: the shorter god is called Aryman, and the taller one - Ormazd. In spite of that division, the singular form - God-predominates in the diaries. Some rays were to belong to the living ones and the other ones - to the dead people. Schreber believed that after death human nerves get out of the body and undergo purification. Then they connect with God and then return in a newborn person:

The nerves of morally fallen people are blackened; morally pure people have white nerves. The more morally a person lived, the closer the condition of his nerves is to perfect white or purity, attributed to divine nerves from the very beginning. In people of very low moral standing, most of the nerves can be totally unusable [3].

Changes that in the patient's opinion took place in his body were not exclusively limited to transformation into a woman. The importance of changes in the body for Schreber himself is proven by the fact that he devoted a separate chapter in his diaries to that issue. Chapter „Damage to coherence of the body by miracles" describes many phenomena and processes that the patient's body was to undergo:

From the very beginning of my connections with God until today my body was incessantly an object of God's miracles. If I wanted to describe each of these miracles in detail, I could fill the whole book with descriptions alone. I can say that there is not a single member or organ of my body that would not be temporarily damaged in result of a miracle, a single muscle that was not pulled to make it move or immobilize it, depending on the nature of the intended effect [3].

The patient wrote that chapter with full awareness of potential reactions of his readers. He also admitted that all the described changes in his body were authentic:

That will be, like my whole story about the miracles done with my body, sound for all people extremely strange and they will perhaps tend to regard it only as the product of pathologically stimulated imagination. Thus, I can only assure you that hardly any memory of my life is more certain for me that the miracles I tell you about in this chapter. For what can be more certain for a human being than what he feels and experiences on his own body? [3].

Schreber also described extensive changes that occurred in his inner organs of the chest and abdominal cavity. The diarist writes that during his stay in the clinic in Leipzig he had a different heart. When his lungs underwent the effect of the miracles, Schreber seriously feared dying of tuberculosis. Many times a lungworm could be found in his lungs. It caused a burning pain resembling that occurring in pneumonia. Schreber's lung lobes underwent total atrophy many times. The patient was not certain whether it was because of the "lung worm" or through some other miracles. That atrophy was accompanied by the sensation that the diaphragm was right under the larynx, and only small remains of the lungs were left between them, which enabled the patient to breathe in a very fragmentary degree. Schreber claimed that he could live without lungs thanks to the "divine rays", which replaced his breathing. At the same time changes affected also other parts of his body. His ribs were completely broken, but thanks to the miracles they grew back together. Schreber claimed that the miracle of narrowing of breasts was the worst. That miracle involved compressing the whole chest, which caused problems with breathing, and the sense of compression extended to the whole body. As he writes himself, the miracle of narrowing breasts has affected him many times:

The miracle of narrowing breasts sporadically occurred in the later years as well, but in fact it belonged to the second half (...) of 1894 and more or less first half of 1895 [3].

Professor Flechsig was in the centre of Schreber's delusions of prosecution during his second hospitalization. According to the patient's opinion, his doctor strongly affected not only his mind, but also his body. Schreber believed that Prof. Flechsig, by means of magic, exchanged his healthy stomach for - „an ill Jewish stomach of much worse quality" [3]. Souls that can do without food acted upon Schreber by miracles, so that he could not feel any pleasure from eating. Schreber claimed that during his treatment in hospital some moments occurred when he lived without stomach. At that time he notified his male nurse of that fact, because lack of stomach prevented him from eating. It also happened that his stomach, though of worse quality, was "conjured up" by souls just before the meal. When there was no stomach, foods and drinks poured out on Schreber's abdominal cavity and thighs. That situation did not lead to his death, because the rays sucked in all the consumed substances. Therefore, Schreber could eat without any obstacles, despite lack of stomach. The sense of constant activity of the rays evoked the sense of total lack of care of his own body. He started to think that he is immune to all illnesses: „Even now I am convinced that I am resistant to all natural influences of diseases; germs of illnesses form in me only in the effect of the rays and then they are removed by the rays in the same way" [3].

Schreber maintained that he had marks on his body 
from leprosy and plague he had suffered from. As time passed, he started to regard himself as an immortal and that he would survive even if he had taken a strong poison:

I do have serious doubts whether I really have been a mortal, since I have been encountering with the rays, whether I could not take the strongest poison without a significant harm to my life and health. For what else can poisons do except destroying some important organs or cause blood disintegration (hemolysis) ? I have experienced both these things countless times already, because of the rays and without permanent harmful effects [3].

In another place of the diaries he remarks that any illnesses whatsoever, or external interferences are unable to deprive him of his life, and death may be caused exclusively because of old age:

Assuming that I would fall into the water, or I would like, which, obviously I do not think about at all, to shoot my head or chest, then probably temporarily, symptoms would occur that correspond to death by drowning or the state of unconsciousness after a gunshot wound, in other case deadly. Would there, however, revival take place as long as the encounter with rays lasted, would the heart rate be stimulate, and therefore- the circulation of blood, would the damaged internal organs and bones be healed. That is the question, which after my previous experiences, I would hardly dare to answer: "no" (...). It seems to me that the only possible cause of my death could be only the phenomenon commonly called senile weakness [3].

As a confirmation of his faultless health, Schreber regarded lack of running nose which used to accompany him every evening. For the readers of the diaries that may seem not a very convincing arguments, but it was convincing enough for Schreber:

As small evidence of the trueness of the fact that my assumption that I became, let us say, inviolable, I want to quote the fact that in my healthy days, every winter I used to have a severe rhinitis for many days, whereas for six years of my stay here (in Sonnenstein treatment institution - W.L.) I almost never had true rhinitis. If now, in a natural way rhinitis would form- which is, after all, what the significance of running nose seems to involve - the rays would immediately flow into the ill part of the body in such an amount that rhinitis would be nipped in the bud [3].

Changes concerning stomach were not the only ones that Schreber noticed in his body. It was many a time that he experienced delusions of gut torsion and changes within esophagus and intestines. At meals he sometimes ate his own larynx, broke his teeth and bit his tongue. Additionally, his moustache slipped into his mouth:

of other internal organs I would also only like to mention esophagus and intestines, which were broken and disappeared many times, then the larynx which I partially ate with my meals more than once... [3].
My teeth were constantly endangered; some of them were frequently broken through miracles. While eating the miracles of biting my tongue were applied to me. The hairs of my moustache were almost regularly slipped into my mouth, so at least for that reason I had to decide to shave it in August 1896 [3].

His spermatic cord was subjected to painful miracles, mainly because of the feelings of delight in his body. Schreber was talking about a miracle that he referred to as „ rotting of underbelly". It was caused by the soul of v.W. (D.P. Schreber does not develop these initials in his diaries. Most probably they refer to dr Weber, who was taking care of him in Sonnenstein). That soul introduced the bacteria of decay into his belly, which made his underbelly rot. Schreber also felt that he would have to rot alive, and additionally, it was accompanied by the stench of decay from the patient's mouth. The process of rotting was reversed by divine rays that entered the intestines and sucked out the decay.

Schreber was the most afraid of the miracles concerning his mind:

The most dangerous miracles seemed to me the ones that were directed against my reason in any possible way. First of all they concerned my head; secondly, it was also spinal cord, which, at that time, besides head, was regarded as the seat of reason. That was during a certain period (I think it lasted a few weeks), more or less in autumn 1894 [3].

Schreber claimed that his spinal cord was dried by the so-called „little people”, who had been put into his feet. He recognized two of them and called by name and surname. These were „small Flechsig” and „small v.W." The diarist claims that he heard his voices when they were having a conversation. Drying his spinal cord made it come out of his mouth in the form of small clouds as he was walking in the garden. That caused in him strong fear connected with the sense of his reason escaping. Drying was not the only effect upon Schreber's nerves. For he claimed that it was many a time that he had experienced that someone had been trying to pull the nerves out of his head to transfer them to the person sleeping in the room next door. These activities were accompanied by the feeling of tension in the head. The pulled out nerves were strong enough to return to the patient's head. Schreber's head was also affected by series of rays: „a phenomenon difficult to describe, of which I can only describe how it works, that is, how my skull was, as if sawed in different directions, which was frequently repeated" [3].

The patient felt that the integument of his skull narrowed, because the bone it was built of partially dispersed through the effect of the rays, but during sleep the skull became a whole (blended together) back again. The patient writes that many times someone tried to cover his nerves with some harmful substance: „One of the agents used at that time was called "an intoxicating poison" [3]. 
The patient recalls that as he had been drinking coffee, the liquid was miraculously taken from his body and transferred to the nerves in his head, which was to make thinking difficult for him.

Besides the nervous system, "miracles" also affected the muscle and bone systems. Schreber's muscles sometimes were to vanish totally and then be reborn. Miracles on muscles were to hinder movements and performing all the activities. Attempts at paralyzing fingers made playing the piano and writing difficult, miraculously evoked pain in the patella made walking difficult. Problems with playing the piano were to result not always from the paralysis of his fingers, but also from the changes in seeing, so that the patient could not read the notes from the score. According to the patient, miracles guided his fingers to wrong keys. The pace of play accelerated as the miracles controlled the muscles of his fingers. Miracles were also responsible for the strings breaking in the piano.

Schreber was also frequently unable to read or write. When he started these activities, he suffered from a strong headache.

The miracles also affected the sensual centers and controlled muscles that closed and opened the eyelids and influenced perception:

Eyes have been important for a long time, because the rays, which, themselves, are equipped with a destructive force, having seen something, lose their acuity in a relatively short time and die in my body. The seen objects can either be visual (eye) impressions, which are received by the rays through my eyes when they are open or, partially, images that I can develop with the use of human imagination as I wish on my internal nervous system, so that they become visible to the rays to a certain extent [3].

The rays that affected Schreber's eyesight were accompanied by voices speaking " the basic language”, in other words "the language of souls". They were persecuting Schreber and controlling the processes of opening and closing the eyes:

...very often someone tried to close my eyes against my will, just in order to deprive me of visual impressions and maintain the damaging acuity of the rays (...). This phenomenon can be observed in me almost in any possible moment; he who tries to watch carefully, will notice that my eyelids, even when I am talking to other people, suddenly fall or close, which, in natural conditions, does not happen to everybody[3].

Schreber writes that Flechsig's and v.W.'s souls were in his eyes and mouth. Thanks to God's omnipotence these souls were partially expelled from Schreber's head. The soul of v.W. took Schreber's thoughts away, and when it placed itself in his eyes, it experienced the same visual impressions, as he did, that is, it looked out through his eyes, when he was looking for some object in his surroundings. The presence of v.W.'s soul resulted in the change of their look. They were "glazed" and a watery matter could be seen in their eyeballs.

Besides the prosecuting activity of the rays and souls upon the patient's eyes, Schreber also describes positive effects. For the patient could look directly at the sun thanks to the rays, without the sense of being blinded. He had visual hallucinations, for he claimed that as he was walking in the garden, he had seen two suns in the sky at the same time [3]. The feeling of physical satisfaction came to Schreber's body in result of strongly developed „soul delight”. It was extremely strong when the judge was lying in bed and imagined a sensual pleasure similar to that experienced by a woman during sexual intercourse. Besides the feeling of physical pleasure, the patient felt pain. These were pains in thighs and calves, paralyses, lumbago and toothaches. That was also accompanied by strong feeling of hunger.

The patient felt all the time that his body was affected by divine and human nerves. Souls and their nerves assumed the forms of tiny, a few millimeter tall people. They moved inside and on the surface of his body. They dealt with closing and opening his eyes: „they stood over the eyes in the eyebrows and from there they pulled the eyelids with spiderweb thin threads depending upon the mood, up and down” [3]. The same "small people” resided on his head, where they were called "small devils" in the language of souls. They performed miracles of destruction. It sometimes happened that these "small people" ate meals with the patient, through which they were more drowsy and less harmful to him. The "small people” performed on Schreber's body the miracle called "head-pressing machine”. It was, besides narrowing of chest, the most hurtful miracle that the patient's body was subjected to. The miracle "head pressing machine" involved the formation of a deep fissure in the skull in the effect of the rays operating from inside. On both sides of that tissue there were "little devils", who, with the use of an appliance resembling a chaser diestock, pressed his head in such a way that the skull became longer and resembled a pear. This activity was accompanied by a severe pain. The patient had been subjected to that miracle for several months. Usually, like in the case of most miracles, their destructive activity was reversed with the participation of divine rays.

Another miracle happening in Schreber's head was the miracle referred to in the basic language of the voices as „v.W.'s whip". The activity of that miracle involved a small part of v. W.'s soul penetrating into the patient's skull. That soul waved a small whip inside it. That activity caused serious destructions and a severe pain. Besides the head bones, also bones of the feet underwent the effect of the miracles. In Schreber's heel painful decay was to appear. Besides, his 
obsessive thoughts he perceived as the voices, forbade him to think about his own body and eat:

I decided to end my life dying of starvation and refused to eat any dishes, even more so that the internal voices kept telling me that in fact it was my duty to die of hunger and in this way, as if, give myself to God as a sacrifice, that every meal I consumed, that my body desired, was an unworthy weakness [3].

Nerves, that through the activity of divine miracles are stimulated to vibrate, in the patient's opinion, are responsible for using particular words by him. For they control the work of his speech organs, lips, tongue and teeth, setting them in motion.

Many a time Schreber thought about suicide and made attempts at taking his own life. The first one took place just after Schreber had been admitted to hospital in Leipzig. After the patient had been admitted to hospital, Prof. Flechsing diagnosed that his illness was caused by a somatic factor, namely: poisoning with potassium bromide. The patient did not agree with that diagnosis, as his illness could not have been caused by a poisoning, because thanks to the activity of divine rays, in his opinion poisoning was impossible:

Countless times I have experienced on my own body, even now, every day I experience that God, for instance, can remove any germ of disease from human body by sending a few pure rays [3].

The main symptom, with which Schreber was admitted to the clinic, was insomnia. Prof. Flechsig, right after the patient's admission, applied the therapy involving administration of chloral hydrate, thanks to which Schreber was to fall asleep. However, the medicines did not work, as they were expected to. The patient got up in the state of strong anxiety and wanted to strangle himself with a towel. His wife disturbed him when he was making that suicidal attempt. However, he did not stop thinking about taking his own life. On the fourth or fifth night after he had been admitted to the clinic Schreber started a fight with male nurses in billiard room. Two nurses immobilized him and transported him to the isolation room. There Schreber undertook another unsuccessful suicidal attempt - he tried to hang himself on a sheet. Voices talking to him encouraged him to commit suicide. He obsessively imagined that he was drowning when taking a bath. He tried to drown himself when accomplishing these ideas:

...each bath I took was connected with the images of getting drowned. They told me - in the language of nervesabout "purifying baths” and „sacred baths”, the latter were aimed at giving me the opportunity to get drowned; I went into almost every bath, overwhelmed with the internal fear that this very bath was to serve ending my life. The internal voices (...) talked to me in this very context and ridiculed me that I do not have manly courage for it; that is why many a time I have tried to submerge my head under water, and the guards in some cases held my feet over the surface of water, so they seemingly enhanced my suicidal intentions with their behavior, many a time they submerged my head, and then, with rude jokes, forced me to emerge and finally leave the water [3].

When Schreber was in Leipzig, he was in constant contact with Professor Flechsig by means of „connecting nerves". In his delusions he asked Prof. Flechsig for potassium cyanide or strychnine (in the „language of souls” referred to as drops of ,juice-poison”) to get poisoned. Schreber claims that in these contacts Prof. Flechsig was fully well disposed and gave the patient hope for his consent:

...during talks lasting for many hours in the nervous connections conditioned administering poison to me, always in a hypocritical way, on certain guarantees, whether I would really drink that poison, if it is given to me etc. And when Professor Flechsig came to visit me as a physician, as a man, he obviously claimed that he did not know anything about such things [3].

At that time, besides obsessive suicidal thoughts, Schreber was accompanied by the convictions that he would be buried alive. Besides, when traveling from the clinic in Leipzig to the institution in Lindenhof, the patient many a time thought about throwing himself under a train. Besides suicidal and thoughts of prosecution Schreber was accompanied by delusions of magnitude. In Schreber's head there were souls of the dead, called „little people” in the „basic language” (serving Schreber to communicate with God and souls). The "little people" coming from other planets and stars, within one night could appear on the patient's head in thousands. They told him stories about the processes destroying planets. The patient described his experiences that can be referred to as symptoms of de-realization. The patient saw other patients, Professor Flechsing, staff of the clinic and his wife „not as human beings, but as conjured human figures on the pattern of «superficially created people»".

The patient's perception of time and space becomes distorted. Time is distinctly extended, the patient felt that nights last hundreds of year. In his opinion the clinic was transferred to another planet:

I considered various possibilities, like this one, whether the whole Flechsig's institution, or the city of Leipzig together with it were "taken out” of the Earth and transferred to some other celestial body - the possibilities suggested to me by voices talking to me by questions, like, for instance, whether Leipzig was still there [3].

The patient had symptoms of de-personalization. The voices informed him that in the past there existed another Daniel Paul Schreber, who was to be more intelligent. The 
patient himself said that there had never been another Daniel Paul Schreber in his family, so he decided that the Daniel Paul Schreber, mentioned by the voices was himself, but from the times, „when he was in full command of his nerves", i.e. before the influence of divine rays. The delusive thoughts and voices manifested themselves in the patient's sense of multiplicity, i.e. he felt as if there were many minds in his head:

...souls being in nervous contact with me were talking about multitude of heads (i.e. a few identities in the same skull), they encountered in me and jumped away frightened, saying something like: „For God's sake, it is a man with many heads" [3].

Schreber had a vision that he traveled inside the Earth and throughout the eras of its development. As a result of delusions, he lost the sense of here and now. The time and space relationships were distorted in him. According to Antoni Kępiński, the pathology of time-space order is one of the main elements of the structure of schizophrenic world [4]. Schreber claimed that his body, undergoing "demasculinization", was filled with female nerves of pleasure, which intensified the strength of attraction of rays. For this reason, scorpions or other creatures similar to crabs or spiders are many times put into his head, which were to cause damages within his head:

They had the nature of souls, so they were talking beings, depending on the place they came from , "arian" scorpions were distinguished, as well as „catholic” ones the first ones were slightly bigger and of stronger build. However, these scorpions regularly came out of my head, not having harmed me in any possible way, after they had found that my nerves were pure and my views were sacred [3].

The souls of Jesuits undertook pestering actions on the patient's body:

"Jesuits", that is, I think, the souls of the dead Jesuits, many times had tried to put into my head another "nerve of destiny, through which my sense of identity was to be changed; the internal walls of my skull were inlaid with another "brain membrane”, to remove the memories of my own "self". All without any durable success. Finally, they tried to blacken my nerves, conjuring into my body the nerves of other (dead) people, probably assuming that blackness (impurity) of these nerves will be given to my own nerves [3].

In Schreber's body there were only beings that tried to destroy him and make his life difficult, but also divine rays that saved him from death.

The durable connection of God with the patient's nerves and the miracles affecting him were to lead to the extermination of all the creatures in the Earth. Schreber, through the connection with the divine rays, was to undergo "de-masculinization". In his opinion, such fate must have been shared by everybody encountering the divine rays:

It is partly connected with the nature of the divine nerves, thanks to which happiness is, if not exclusively, then at least partially - identified with the simultaneously felt delight in high intensity (...), while on the other hand, with, as it seems, with the plan constituting the basis of the order of the world, which will allow for renewing the human race in case of the world's disasters which will make it necessary to annihilate the humanity on some celestial body - in specie intended or not [3].

Schreber claimed that in the Earth, not like in other planets, the extermination of humanity has not happened yet, because "the inhabitants of our Earth are still more ethically pure" [3].

Schreber directly confirmed the theory of disasters by Georges Cuvier. He connected his images of his own fate with it. He believed that after the world's disaster just one man would be saved: the one who was most morally decent, the one who was called "the wandering Jew" by the voices that had been talking to him. That man -Schreber believed that it would be himself - would be transformed into a woman to give birth to new generations that will populate the world. These delusions of magnitude, connected with „de-masculinization”, were constantly accompanied by obsessive thoughts of prosecution. Schreber could not be left by the idea that his feminine body would be sexually abused and then abandoned and left to rot. These thoughts were accompanied by events that, according to the patient, confirmed the rape that was planned on him:

...I was kept in bed for weeks after my clothes had been taken away from me, as I believe, to make access to me easier for lustful experiences that could have been caused by female nerves penetrating me in greater and greater numbers; agents (medicaments), which, in my view, served the same purpose and, therefore I abstained from taking them and when the guards poured them into my throat by force, I spat them out again [3].

Schreber felt that a "god” or an „apostle" came to live in his underbelly, which was a personification of rays achieved from the state of bliss:

Here a phenomenon happened that I have observed also in many other cases, namely, that friendly souls always rather turned to the areas of sexual organs (to the abdomen etc..), where they were just a bit, or not at all harmful and they were hardly a nuisance, whereas more hostile souls always headed for the head, which they wanted to harm somehow, they especially settled at the left ear in a very pestering way [3].

Schreber claimed that the soul of Prof. Flechsig, in the form of a large bundle or roll resembling cotton wool or yarn, entered into his abdomen. That soul was too big for Schreber to digest it. It had mercy upon him and left his body through his mouth. Schreber maintained that 
after that event he took whole souls or parts of them into his mouth and they left in it an unpleasant taste or smell. Besides Prof. Flechsig, also other patients from Sonnenstein entered his body, leaving parts of their bodies in it as a rotten mass. Schreber's body accumulated cadaverous venom and putrefactive substances originating from rays that wanted to deprive him of reason.

Schreber looked for explanation to his experiences in science. And he was not an ignoramus who rejected the medical knowledge of that time. He was convinced that what he experienced is not a symptom of sick psyche, but a metaphysical experience, and he tried to find confirmation of his theses in scientific research. While his stay in Leipzig, the patient studied the most modern psychiatry handbook of that time by Emile Kräpelin. Analyzing the psychiatric characteristics of psychotic patients he gave arguments confirming that his experiences had nothing in common with mental illness. He found out that voices and visual hallucinations he experienced were the result of the actions of „interplanetary nerves” and not the symptoms of disease. Schreber emphasized that Kräpelin was guided by the rationalism of Enlightenment, so he did not notice the activity of supernatural forces in the cases he described. As the argument that the attitude towards God was not the result of delusions, Schreber presented his pre-illness attitude towards religion and God. The German judge believed that if before his nervous breakdown he had not been a religious person, he could not suffer from delusions based on religion:

(...) an illusion of being in touch with God or with souls of the dead may occur only in people who included already stable faith in God and immortality of the soul in the state of nervous excitation. In my case, however (...) it was not so [3].

The thought that he experienced God's miracles totally displaced his consciousness of paranoia. He admitted that he was only mentally ill, and his main ailment was lack of sleep. Schreber was constantly convinced that the sense of warmth or cold result from miracles affecting his body:

...in the case of miracle cold blood is displaced from its parts, which causes a subjective feeling of cold, whereas in the case of the miracle of heat, something contrary takes place, blood is pumped into the face and head, which generally would feel better in cooler conditions [3].

To feel relief the patient started cooling his body:

...I myself was frequently forced to look for coolness and heat. Especially in the first years of my stay in this institution (i.e. in Sonnenstein - W.L.), when the delight of soul had not achieved that intensity it has now, frequently it was a necessary means to draw the rays away to the freezing parts of the body, especially hands and feet, this way preventing head from intentional harmful activities. Frequently it seemed that for that purpose I kept my hands next to icy trees in winter or embraced snowballs with them so long that they were almost frozen solid [3].

In order to cool his body, the patient, except touching cold objects, put out his bare feet through the window bars to cool them in the rain. Sometimes, when having a bath, he showered using cold water only. Such activities were aimed at withdrawing the rays from the patient's head. He believed that thanks to cooling down he became fully healthy and resistant to the effects of all dangerous miraculous phenomena concerning his head and other parts of his body.

The author of diaries does not disregard his problem with defecation. He claimed that like all other processes in his body also defecation is regulated by miraculous activities. In the patient's opinion the process of bowel movement caused damage to reason by withdrawal of divine rays. Schreber, describing problems with defecation, was talking about problems caused by other people. These obstacles involved sending someone from the patient's surroundings to the toilet the moment he needed to use it. Schreber claimed that frequency of such occurrences excluded coincidence. Therefore, the patient started to defecate into a bucket, which was connected with an extremely strong feeling of pleasure each time. The patient clearly stated that the process of defecation was pleasant to him:

For relieving the pressure caused by stool remaining in the intestines results for the nerves of pleasure with an intense sense of delight. It is the same with urination. For that reason, during defecation and pissing the rays were always united, without any exception whatsoever and it is for this reason that constant attempts are made at miraculous canceling of the need to defecate or to piss, though that is most often in vain, whenever I take to performing these natural functions [3].

S. Freud compares the pleasure of defecation occurring in Schreber to autoerotic behaviors - components of children's sexuality [2].

On the basis of the expertise prepared in 1899 by Schreber's doctor - Mr. Weber, the following main symptoms of his disease can be brought out. These are:

hypochondriac thoughts (the patient maintained that his brain was softening and his body was wounded in the effect of torturing, he was a rotting corpse and was infected by plague),

- serious hypersensitivity to light and sound (hyperesthesia),

- thoughts of prosecution,

- increased sight and hearing disorders,

- mood disorders,

- delusions of being possessed („his whole body submits to repulsive manipulations"),

- delusions of magnitude (the patient maintains that he is to give birth to a new generation 
of people and that there exists "the holy purpose" that he must fulfill),

- $\quad$ autism (the patient was totally isolated, did not establish any contacts, did not demonstrate any interest in his surroundings),

- cessation of moving (hallucination stupor),

- hallucinations,

- suicidal thoughts and attempts at committing suicide[5].

Schreber described the experiments that his body was subjected to in two categories. The first category includes experiences resulting from his sense of being prosecuted and constitute an element of his delusions of prosecution. In the second one he fulfilled himself as an exceptional and extraordinary person, which should be connected with his delusions of magnitude. Changes in perceiving one's own body in psychiatry are referred to as dysmorphophobia. These perception disorders are accompanied by strong and permanent sense of fear [6]. In Schreber that fear concerned exclusively the effects damaging his body, connected with delusions of prosecution. Dysmorphophobia is observed as a symptom of neurosis, but most frequently it occurs in psychoses, especially in the initial period of schizophrenia [7]. In case of Schreber we can talk about dysmorphognosia, that is recognizing changes taking place in one's body [8]. Sometimes the disorder is the reason for the patient's aiming at changing image and that was the case with Schreber, when he started to shave his body hair and dress in women's clothes. Schreber's sense of experiencing changes in the body and constant acquiring female features might result from his sexuality disorders. Schreber displaced the problem of his own sexual identification from his consciousness. It cannot be stated for sure that Schreber had homosexual tendencies, but reports of his ideas of himself copulating with a man as a woman can confirm that hypothesis. Visualisation of Schreber's sexual desires might have occurred in his delusions. Distinct problems with gender identification, displaced with projecting their source outside (typical of creative symptoms) overlapped with the progressing personality disintegration. Changes in the body became the element of reference to changes in psyche. Transformation into a woman, progressed in Schreber's consciousness and reflected in his body, is an indicator of his internal changes. The process of progressing illness was not inhibited by anything, the forms of therapy used in these times did not give satisfying effects. Schreber, possessed by permanent psychotic states, was looking for reasons for his experiences in external factors.

In S. Freud's opinion, D.P. Schreber suffered from delusion of persecution. The patient had an erotic fantasy of giving himself to Professor Flechsig. His personality resisted that fantasy, according to the creator of psychoanalysis. That caused the delusion of prosecution, where the desired one became the persecutor, and the contents of fantasy became the content of prosecution. This caused paranoia (paranoid dementia) in Schreber. Freud admitted that he did not directly contact the author of diaries, and his scientific reflection is based exclusively on Schreber's work. At the time when Schreber published his diaries there was not such description concerning schizophrenia yet, as we have nowadays. Shortly before Schreber's death, i.e. in 1911, Freud's article about him appeared. Freud himself described his view in 1910, also before the publication of Eugenius Bleuer's crucial textentitled: „Dementia praecox or a group of schizophrenias", where the description of schizophrenia(s) was presented. At that time in psychiatry the term "dementia praecox" (early dementia) by Emile Kraepelin coined. Freud, in his study on Schreber, alluded to a significant convergence of Schreber's symptoms with the case of a patient with dementia praecox described by Carl Gustav Jung. Freud especially strongly emphasized the connection of paranoia with dementia praecox, remarking that the second term was chosen especially awkwardly. Due to that awkwardness, Freud suggested the term paraphrenia, which was to be the name for dementia praecox and paranoias combined in one nosological unit. The term „paraphrenia” did not catch on and was displaced by the term "schizophrenias” proposed by Bleuler (E. Bleuler used the plural form on purpose, because he treated schizophrenias as a group of psychoses).

One of the contemporary psychoanalysts, Zvi Lothane criticized Freud's statement that Schreber was a homosexual and paranoiac. According to Lothane, the judge mainly suffered from depression, and his delusions and hallucinations resulted from the fact that he was administered opiates and bromine. In his opinion, detaining Schreber was illegal. What Schreber calls "murder on the soul", Lothane deciphers as violating personal freedom that assumed the dimension of legal prosecution with the use of psychiatric agents. Lothane claims that Freud missed the fact that the judge had the so-called present neurosis, i.e. the unsatisfied sexual craving of many years, which can be observed e.g. in prisoners. Missionist thinking, manifested many times in the diaries, according to Lothane, did not result from paranoia, but was the effect of the spirit of the times, when Masonic movements were popular (especially in the high society that Schreber belonged to). (Schreber writes in his diaries about Duke Adam Kazimierz Czartoryski, as one of the „wandering Jews”, who certainly belonged to the Masonic lodge and took part in occultist practices).

As late as today, the diaries of D.P. Schreber constitute a reason for many discussions and evoke strong emotions among their readers. My article is restricted mainly to disorders in perceiving his own body that occurred in D.P. Schreber, who suffered from a psychosis. It does not present the description of all delusions, but only of those related to changes in the patient's body. Creativity of Schreber's 
mind, taken over by the disease, deserves respect. Vividness, multiculturalism and abundance of motifs he included in his delusions prove his vast knowledge and intelligence. In his case, the thin border between reality and fantasy was blurred. Schreber was unable to look into his experiences. Lack of criticism of experiences totally ruined him. All attempts at rationalization played the role contrary to the assumed one. The way of perceiving the body by the schizophrenic patient, Schreber presented in the article is a good measure of changes in his psyche. This life rationalist due to his illness was unable to find neither in himself nor in his surroundings the element whose nature or features could turn him to reality. The omnipotence of schizophrenia is absolute and ruthless. It can raise doubts in the patient, concerning even in his own body. What seems constant - the body, that is the anatomical structure, through illness becomes fluid and undergoes changes. The alleged changes in Schreber's body, as this work shows, were not subtle. Quite contrary they were dramatic and denied the possibility of survival. That, however, did not raise any doubts in the patient, as he passively subdued to his delusions. It has to be found that it was the false convictions that governed Schreber in every moment of his illness. And, as it might seem, the enormous absurdity of his experiences and changes that took place in himself were not enough to exclude the being. The text of "Diaries” allows to look at the process of changes in the psyche taking place as an effect of illness, from rarely fully accessible perspective - not the perspective of an observer from outside, a witness to the events, standing aside, but the perspective of the patient himself, the person who experiences the illness. In the history of Schreber's illness an extraordinary thing happened - his delusions of the set of false convictions were accomplished by him to a significant extent. All changes in affective states manifesting themselves with instability had a huge reference to Schreber's carnality. His aiming at self-annihilation (suicidal attempts are frequent in schizophrenia) interpenetrated with the sense of immortality and great sense and purposefulness of existence. All these ambivalences were reflected in the body. Simultaneously, strong antagonisms were in symbiosis. The patient subsided to them uncritically. The body, which has to be healthy in order to fulfill its function, in Schreber's delusions experienced complete degradation. Simultaneously, it underwent destruction and healing. Schreber's body was a sanctity that was to save humanity by connection with god, but also a profanation that drew pleasure from rape. What for a healthy person is a total contradiction and what rejects any sense whatsoever, for an ill person was something ordinary and not surprising at all, with which he certainly reconciled. Undoubtedly, „Great Thoughts of a Mental Patient" is an exceptional work in the scale of the world and an excellent study of a mental illness.
W prezentowanym artykule chciałbym zastanowić się nad stosunkiem pomiędzy ciałem a umysłem w sytuacji osoby $\mathrm{z}$ zaburzeniami psychicznymi. Podjęty problem będzie dotyczył zmian $\mathrm{w}$ postrzeganiu własnego ciała jakie wystąpiły u Daniela Paula Schrebera pod wpływem choroby psychicznej. Aby przyjrzeć się postawionemu problemowi należy najpierw przedstawić krótką historię życia tego człowieka. D.P. Schreber urodził się 25 lipca 1842 roku w Lipsku w Niemczech. Jego rodzina była wysoko postawiona głównie dzięki temu, że ojciec D.P. Schrebera, Daniel Gottlob Moritz Schreber był powszechnie znanym i szanowanym ortopedą. D.P. Schreber miał starszego o trzy lata brata Gustava, starszą o dwa lata siostrę Annę, cztery lata młodszą siostrę Sidonie i o sześć lat młodszą siostrę Klarę. Głową rodziny był ojciec, matka Paulina pozostawała w jego cieniu do momentu wypadku, kiedy to Moritz został uderzony w głowę drabiną. To zdarzenie zmieniło ojca Schrebera. Od tamtej pory zaczął miewać stany depresyjne i natrętne myśli o treściach agresywnych. Nie tylko ojciec Schrebera miał problemy natury psychicznej, na depresję cierpiał jego starszy brat Gustav, który po śmierci ojca stanął na czele rodziny. Nie wytrzymał presji i w wieku 38 lat popełnił samobójstwo. W 1877 roku to Daniel Paul zaczął przejmować obowiązki i towarzyszącą im presję. Rok po samobójczej śmierci brata D.P. Schreber wziął ślub z Sabine
Behr, po czym zaczęły pojawiać się u niego pierwsze objawy zaburzeń nerwicowych. Młody i zdolny prawnik energicznie zaangażował się w działalność samorządową. Mimo starań o dzieci żona Daniela Paula dwukrotnie poroniła. Jesienią w 1884 roku kandydował do Reichstagu i, mimo że był faworytem, nie został wybrany. Ta porażka dotknęła Paula. Zaczął leczyć się w spa dr. Richtera. Ówczesna hydroi farmakoterapia okazały się jednak nieskuteczne. Daniel Paul cierpiał na bezsenność, odczuwał niepokój, miał myśli samobójcze i był pobudzony. Schreberowi pomaga dopiero prof. Flechsig z Uniwersyteckiej Kliniki Psychiatrycznej w Lipsku, skąd 1 czerwca 1885 roku Schreber został zwolniony z poczuciem pełnego wyleczenia. W kolejnych latach wciąż nieskuteczne były próby uzyskania przez Schreber potomstwa, ale jego kariera zawodowa rozwijała się dobrze. W czerwcu 1893 roku Schreber otrzymał wiadomość o powołaniu na stanowisko w Wyższym Sądzie Krajowym, a w październiku tegoż roku otrzymuje stanowisko Prezesa Senatu. 23 listopada po konsultacji z prof. Flechsigiem zrozpoznaniem depresji, którejtowarzysząmyślisamobójcze, Schreber został po raz drugi przyjęty do Uniwersyteckiej Kliniki Psychiatrycznej w Lipsku. Jesienią 1894 roku został ubezwłasnowolniony. Z Lipska został przeniesiony na dwa tygodnie do zakładu leczniczego w Lindenhof, a potem do Sonnenstein. Od 1897 roku Paul zaczął pracować 
nad pamiętnikami i pisał pierwsze wnioski o wypis ze szpitala. Tak zaczęła się walka Daniela Paula o odzyskanie wolności, która skończyła się wyrokiem z 14 lipca 1902 roku, wydanym przez Wyższy Sąd Krajowy o zniesieniu kurateli, a 20 grudnia Schrebera zwolniono z zakładu. Po staraniach autora w 1903 roku ukazały się drukiem jego pamiętniki. Zostały one wydane pod tytułem „Wielkie myśli nerwowo chorego". W tym czasie stan Schrebera można określić jako dobry. Nie był to jednak koniec jego problemów psychicznych. Trzeci epizod choroby wybuchł w 1907 roku. Bezpośrednim powodem nawrotu choroby był atak apopleksji żony Schrebera, który miał miejsce 14 listopada. 27 listopada Schreber trafił do zakładu Leipzig-Dösen. 14 kwietnia 1911 roku umarł pogrążony w obłędzie.

Jak wynika $\mathrm{z}$ chronologii, zdarzenia opisane w pamiętnikach dotyczą czasu sprzed 1903 roku. Autor w swoim dziele skupił się na okresie od 1893 do 1902 roku, kiedy przechodził pierwszy nawrót choroby. Pamiętniki Schrebera nie okazały się, jak myśleli jego lekarz, rodzina i rozpatrujący jego sprawę sędziowie, nieznaczącą publikacją będącą wynikiem aktu twórczego chorego umysłu autora Już od momentu kiedy się pojawiły były one bardzo popularne w środowisku ówczesnych psychiatrów. Osobne studia na ich temat napisali Z. Freud i C.G. Jung. Po dziś dzień stanowią przedmiot uwagi osób interesujących się urojeniami, są tłumaczone i wydawane na całym świecie. Zvi Lothane nazwał „Pamiętniki” najwspanialszą książką, jaka kiedykolwiek została napisana przez osobę przebywającą w szpitalu. Jego zdaniem ,jest to dzieło sztuki, filozoficzny poemat prozą, na modłę Fausta Goethego" [1].

Po tym krótkim wstępie, przybliżającym sylwetkę D.P. Schrebera chciałbym przejść do przedstawienia $\mathrm{i}$ analizy postawionego $\mathrm{w}$ tytule tego artykułu problemu. Choroba, zaburzająca odbiór rzeczywistości zewnętrznej i wewnętrznej, generowała w autorze „Pamiętników” poczucie zmian dokonujących się $\mathrm{w}$ jego fizyczności Wraz z jej rozwojem następowało $\mathrm{w}$ mniemaniu chorego przeobrażenie jego własnego ciała. Na początku nawrotu choroby pojawiły się u Schrebera objawy hipochondrii. Chory zauważył, że jego ciało uległo wychudzeniu. Nie wspomina przy tym, że powodem tego było odmawianie w owym czasie jedzenia. Bezpośredniej przyczyny odmawiania jedzenia Schreber nie zdradza. Brak w pamiętnikach informacji o występujących $\mathrm{w}$ owym czasie urojeniach związanych $\mathrm{z}$ jedzeniem. 0 tych urojeniach chory pisze $\mathrm{w}$ kontekście późniejszych wydarzeń. Schreber zaczął uważać, że jako człowiek wybrany przez Boga miał ulec procesowi „odmężczyźnienia” i zbawić świat poprzez narodzenie nowego pokolenia ludzi, które zastąpi to poddane zniszczeniu. Zygmunt Freud w swoim studium poświęconym Schreberowi postawił tezę, że „odmężczyźnienie” to określenie na kastrację, której Schreber zaczął podświadomie pragnąć. Zdaniem twórcy psychoanalizy Schreber miał erotyczną fantazję oddania się swojemu lekarzowi z Lipska prof. Flechsigowi. Miała być to kobieca (homoseksualnie bierna) fantazja życzeniowa. Osobowość Schrebera stawiała jej opór, co wywołało stan manii prześladowczej, w której upragniony stał się prześladowca, a treść fantazji treścią prześladowania[2]. Ten sposób myślenia Freuda pokrywał się $\mathrm{z}$ jego teorią o genezie paranoi, która miała zawsze wynikać z urojeń prześladowczych wywołanych przez pragnienia homoseksualne. Pomijając wyjaśnienia Freuda na temat genezy występujących u Schrebera wyobrażeń o jego przemianie w kobietę, muszę stwierdzić, że to wyobrażenie było dla chorego totemem, który stał się celem jego życia. Totem ten miał świadczyć o jego świętości i wyjątkowości, a przy tym był dowodem dla Schrebera na istnienie Boga, który wyznaczył go do roli zbawiciela. Myśl o przemianie w kobietę została poprzedzona wyobrażeniem oddania seksualnego, które we śnie lub po przebudzeniu (autor pamiętników sam nie jest w stanie dokładnie określić) nawiedziło chorego:

...kilka razy nad ranem, jeszcze leżąc w łóżku (już nie wiem czy w półśnie, czy już na jawie), miałem wrażenie, które mnie w najwyższym stopniu poruszyło, gdy potem już $w$ stanie całkowitego czuwania o tym rozmyślałem. Było to wyobrażenie, że właściwie naprawdę pięknym uczuciem musi być być kobieta ulegającq podczas stosunku płciowego[3].

To wyobrażenie stało się początkiem rozwijających się w umyśle chorego urojeń, które wraz z rozwojem choroby zaczęły tworzyć bardzo rozbudowane konstrukcje. Zjawisko „odmężczyźnienia” Schreber zaczął zaliczać do działających na jego ciało cudów. Opisał ten proces następująco:

Zgodne z porządkiem świata wydawały się być jeszcze najbardziej te cuda, które zdawały się być jakoś powiązane $z$ odmężczyźnieniem, jakie miało być przeprowadzone na moim ciele. Należały do tej grupy cudów zwłaszcza rozmaite przeobrażenia mych narządów płciowych, sporadyczne przypadki występujq̨ce (szczególnie w łóżku), jako zapowiedź rzeczywistego wciąnięcia członka, częściej jednak - gdy w procesie tym uczestniczyły przeważnie nieczyste promienie - jako zmiękczenie tegoż zbliżone do prawie całkowitego rozpuszczenia się; dalej wyciagnięcie czarami włosów zarostu, zwłaszcza wasów, wreszcie zmiana całej postaci (zmniejszenie rozmiaru ciała) polegająca prawdopodobnie na koncentracji kręgów pleców i może także substancji kostnej ud. (...) sam mam przy tym wrażenie, jakby moje ciało zmniejszyło się o jakieś sześć do ośmiu centymetrów, czyli że zbliżyło się do żeńskich rozmiarów[3].

Zmiana w kobietę w myśleniu Schrebera miała być podporządkowana misji jaką Bóg wyznaczył mu na ziemi. Schreber uważał, że jest predestynowany do uratowania świata, bowiem miał być stwórcą nowych ludzi, kiedy ci obecnie zaludniający ziemię zginą. Schreber w swoich 
pamiętnikach porównuje się do Chrystusa, nazywa się Żydem Wiecznym Tułaczem, który w jego urojeniach reprezentuje zbawcę świata. Zdaniem Schrebera nie on pierwszy $\mathrm{w}$ historii został przeznaczony do przemiany $\mathrm{w}$ kobietę. Biblijny Noe także miał po potopie ulec procesowi „odmężczyźnienia”, a Romulusa i Remusa urodził zamieniony w kobietę mężczyzna:

Coś podobnego do poczęcia Jezusa Chrystusa przez niepokalana dziewicę - to znaczy taka, która nigdy nie obcowała cieleśnie z mężczyzna - zaszło w moim własnym ciele. Dwa razy z osobna (a to w czasie, gdy byłem jeszcze $w$ zakładzie Flechsiga) posiadałem, nawet jeśli nieco wadliwie rozwinięty, żeński organ płciowy i odczuwałem w mym ciele drgania, jakie odpowiadaja pierwszym ruchom ludzkiego embrionu. Za sprawa boskiego cudu rzucone zostały bowiem $w$ me ciało odpowiednie, podobne do męskiego nasienia, boskie nerwy; miało więc miejsce zapłodnienie[3].

Schreber miał ulec „odmężczyźnieniu”, ponieważ

Bóg zaczął kontaktować się z nim przy udziale „promieninerwów":

wedle mojego osq̨du dla porzq̨dku świata tendencję, zgodnie z która $w$ pewnych okolicznościach musi dojść do „odmężczyźnienia” (zmiany w kobietę) człowieka („widującego duchy”), który wszedł $w$ niedajacy się już więcej przerwać kontakt z boskimi nerwami (promieniami)[3].

Schreber pomimo powtarzanych sobie po wielokroć zdań: „nie myśleć o określonych częściach ciała” (s. 140) nie był w stanie przemóc anankastycznych myśli. Wciąż był skupiony na swoim ciele i odczuwał dokonujące się w nim zmiany, tj. że jego męskie ciało ulega transformacji w kobiece. Nieprzerwanie miał wrażenie obecności w swoim ciele „żeńskich nerwów rozkoszy”. Aby bardziej przypominać kobietę kazał sobie zgolić wąsy oraz zaczął rozbierać się do połowy i nakładać na siebie damską biżuterię.

Głosy, które Schreber słyszał powtarzały mu komendę aby „zdjął buty” co „w języku dusz” (tak określał swoje omamy słuchowe) jest określeniem na „odmężczyźnienie”. Odczucie posiadania kobiecego ciała zaczęło pojawiać się u Schrebera najpierw na ramionach i dłoniach, potem rozprzestrzeniło się na nogi, piersi, pośladki i pozostałe części ciała. Chory wierzył, że jego przemiana wynika z predestynacji:

...uświadomiłem sobie bez najmniejszych wątpliwości, że porządek świata koniecznie żąda odmężczyźnienia, czy mi ono osobiście odpowiada, czy nie, i że dlatego nie pozostaje mi $w$ ramach rozsqadku nic innego, jak tylko pogodzić się z myślq o przemianie w kobietę[3].

Naturalną konsekwencją odmężczyźnienia miało być zapłodnienie, którego dokonać miały „boskie promienie”. Z kobiecego ciała chorego miała narodzić się nowa ludzka rasa. Pomimo nawoływaniu głosów, że zamiana w kobietę będzie dla niego hańbą i powodem do wstydu, Schreber był przekonany o potrzebie poświęcenia swojej męskości.
Wierzył, że poniżenie, którego doświadczy poprzez „odmężczyźnienie” zostanie okupione uratowaniem świata. Myślenie o przemianie w kobietę nabrało z czasem u chorego charakteru obsesji. Nie był on w stanie wyobrażać sobie siebie samego grającego na fortepianie, stojącego przed lustrem, leżącego w łóżku czy schylającego się po coś bez posiadania piersi i żeńskich narządów płciowych. Zdaniem Schrebera zmiany w jego ciele były na tyle wyraźne, że każda obcująca z nim osoba byłaby w stanie je zauważyć.

W czasie zbliżenia moje piersi robiq wrażanie dość pełnych piersi kobiecych; zjawisko to może być dostrzeżone własnymi oczami przez każdego, kto chce mnie obserwować. (...) każdy, kto zobaczyłby mnie stojacego przed lustrem z odsłonięta górna częścią korpusu (tym bardziej, jeśli iluzja poparta byłaby jakq̨ś damska ozdoba), odebrałby niekwestionowane wrażenie, że patrzy na górnq część ciała kobiety[3].

W związku ze sprawą sądową o zniesienie ubezwłasnowolnienia Schreber żądał, aby przebadał go lekarz, który uwiarygodniłby jego transformację w kobietę i zaprzeczyłby przypisywaniu tej transformacji miana urojenia.

Zdaniem Zvi Lothana wyobrażenia Schrebera o transformacji $\mathrm{w}$ kobietę miały podłoże mesjanistyczne. Chory odwoływał się nie tylko do narodzin Jezusa, ale również do stworzenia człowieka opisanego w księdze Genesis. Jego zdaniem Bóg, który stworzył świat posiadał obie płci, a Adam jako pierwszy człowiek został stworzony jako istota obojnacza[1].

Schreber permanentnie pogrążony był w urojeniach. Przez większość czasu miał omamy. „Nerwypromienie" oddziaływały na Schrebera bez chwili przerwy. Uważał, że większość promieni pochodziła od Boga, dokładniej mówiąc bogów, ponieważ Schreber zaznacza, że bogów jest dwóch: niższy bóg nazywa się Aryman, a wyższy Ormazd. Pomimo tego podziału w pamiętnikach przeważa liczba pojedyncza - „Bóg”. Inne promienie miały należeć do żywych, a inne do zmarłych ludzi. Schreber uważał, że po śmierci nerwy człowieka wydobywają się z ciała i ulegają oczyszczeniu. Następnie łączą się z Bogiem, po czym powracają w nowo narodzonym człowieku:

Nerwy moralnie upadłych ludzi sq zaczernione; ludzie moralnie czyści mają nerwy białe. Im bardziej moralnie człowiek żył, tym bardziej kondycja jego nerwów jest zbliżona do doskonałej bieli lub czystości, które nerwom boskim sq właściwe od samego początku. U ludzi stojących moralnie bardzo nisko większa część nerwów może być w ogóle nie do użytku[3].

Zmiany, które zdaniem chorego zachodziły w jego ciele nie ograniczają się wyłącznie do przeobrażenia w kobietę. 0 wadze zmian w ciele dla samego Schrebera świadczy fakt poświęcenia temu zagadnieniu oddzielnego rozdziału w jego pamiętnikach. Rozdział „Uszkodzenie 
cudami spójności ciała” opisuje wiele zjawisk i procesów, którym ciało chorego miało być poddane:

Od samego początku mych powiq̨zań z Bogiem aż do dnia dzisiejszego ciało moje było nieustannie przedmiotem boskich cudów. Gdybym chciał szczegółowo opisać każdy z tych cudów, mógłbym samymi tylko opisami wypełnić cała książkę. Mogę powiedzieć, że nie ma chyba jednego członka albo narządu mego ciała, który by nie był przejściowo uszkodzony na skutek cudu, jednego mięśnia, którym by nie szarpano, by w zależności od charakteru zamierzonego efektu wprawić go w ruch albo unieruchomić[3].

Chory napisał ten rozdział z pełną świadomością potencjalnych reakcji jego czytelników. Przyznawał przy tym, że wszystkie opisane zmiany w jego ciele były autentyczne:

Będzie to, jak cała moja opowieść o czynionych z moim ciałem cudach, brzmieć dla wszystkich ludzi ponad miarę dziwnie i pewnie będq oni skłonni uznawać jq tylko za wytwór chorobliwie pobudzonej fantazji. Wobec tego moge tylko zapewnić, że prawie żadne wspomnienie $z$ mojego życia nie jest dla mnie pewniejsze niż opowiedziane $w$ tym rozdziale cuda. Gdyż cóż pewniejszego może być dla człowieka, niż to, czego doznaje i doświadcza na własnym ciele?[3].

Schreber opisał również szerokie zmiany jakie wystąpiły w jego narządach wewnętrznych klatki piersiowej i jamy brzusznej. Pamiętnikarz pisze, że w trakcie pobytu w klinice w Lipsku miał inne serce. Kiedy jego płuca zostały poddane wpływom cudów, Schreber poważnie obawiał się śmierci na gruźlicę. W jego płucach wielokrotnie znajdował się płucny robak, powodujący piekący ból, który przypomina ten towarzyszący zapaleniu płuc. Wielokrotnie płaty płucne Schrebera zupełnie zanikały. Chory nie miał pewności, czy to poprzez działanie „płucnego robaka” czy przez inne cuda. Temu zanikowi towarzyszyło odczucie, że przepona znajduje się bezpośrednio pod krtanią, a między nimi pozostały tylko niewielkie resztki płuc, które w bardzo szczątkowym stopniu umożliwiały oddychanie. Schreber twierdził, że mógł przeżyć bez płuc dzięki „boskim promieniom”, które zastępowały mu oddychanie. W tym samym czasie zmiany dotykały również innych części jego ciała. Jego żebra zostały całkowicie połamane, ale dzięki cudom znów zrastały się w całość. Schreber twierdzi, że najgorszy był dla niego cud zwężenia piersi. Cud ten polegał na ściskaniu całej klatki piersiowej, co powoduje kłopoty z oddychaniem, a uczucie ucisku udziela się na całe ciało. Jak sam pisze cud zwężania piersi wpływał na niego wielokrotnie:

Cud zwężania piersi występował także jeszcze sporadycznie $w$ latach późniejszych, jednak w gruncie rzeczy należał on (...) do drugiej połowy 1894 i mniej więcej pierwszej połowy 1895 roku[3].

Osoba prof. Flechsiga była w okresie drugiej hospitalizacji w centrum urojeń prześladowczych Schrebera. W przeświadczeniu chorego prowadzący go lekarz miał silny wpływ nie tylko na jego umysł, ale także na ciało. Schreber uważał, że prof. Flechsig przy pomocy czarów podmienił jego zdrowy żołądek na - „chory żydowski żołądek dużo gorszej jakości” [3]. Dusze, które mogą obejść się bez pożywienia, działały cudami na Schrebera tak, aby ten nie mógł odczuwać żadnej przyjemności ze spożywania pokarmów. Schreber twierdził, że zdarzały się w trakcie jego hospitalizacji momenty, kiedy żył bez żołądka. Zgłaszał w owym czasie ten fakt pielęgniarzowi, ponieważ brak żołądka uniemożliwiał mu jedzenie. Zdarzało się też, że żołądek, mimo że gorszej jakości, był „wyczarowywany przez dusze" tuż przed samym posiłkiem. Kiedy żołądka nie było, spożywane potrawy i napoje rozlewały się Schreberowi w jamie brzusznej i udach. Ta sytuacja nie doprowadzała do śmierci, ponieważ wszystkie spożyte substancje były wysysane przez promienie. W związku z tym Schreber mógł jeść mimo braku żołądka, bez przeszkód. Odczucie ciągłej działalności promieni wyzwoliło u Schrebera poczucie zupełnego braku troski o własne ciało. Schreber zaczął myśleć, że jest odporny na wszelkie choroby: „Także i teraz żywię przekonanie, że jestem odporny na wszelkie naturalne wpływy chorobowe; zarodki chorób powstają we mnie tylko na skutek działania promieni i są potem tak samo przez promienie usuwane."[3].

Schreber utrzymywał, że na swoim ciele ma ślady po przebytych trądzie i dżumie. Z czasem zaczął uważać, że jest nieśmiertelny i przeżyłby nawet gdyby zażył silną truciznę:

Mam wręcz poważne wątpliwości, czy w ogólne jestem, jak długo trwa obcowanie z promieniami, śmiertelny, czy na przykład nie mógłbym przyjąć najmocniejszej trucizny bez znacznej szkody dla mego życia i zdrowia. Bo cóż innego moga zdziałać trucizny, niż zniszczyć jakieś ważne narząy lub powodować rozkład krwi? Obydwie te rzeczy przytrafity mi się za sprawa promieni i bez trwałych szkodliwych skutków już niezliczone razy [3].

W innym miejscu pamiętników zaznacza, że jakiekolwiek choroby bądź zewnętrzne ingerencje nie są w stanie pozbawić go życia, a śmierć może nastąpić wyłącznie ze starości:

Zakładając, że wpadłbym do wody, albo chciałbym, o czym oczywiście nawet $w$ przybliżeniu nie myślę, postrzelić sobie głowę lub pierś, to prawdopodobnie chwilowo wystapiłyby symptomy odpowiadające śmierci przez utopienie się albo stanowi nieświadomości po w innym przypadku śmiertelnej ranie postrzałowej. Czy jednak, jak długo trwa obcowanie z promieniami, nie miałoby miejsce ponowne ożywienie, czy nie zostałaby pobudzona akcja serca, a tym samym obieg krwi, czy nie zostałyby uleczone zniszczone wewnętrzne narządy i kości, to pytanie, na które po mych wcześniejszych przeżyciach prawie nie odważyłbym się odpowiedzieć przecząco. (...) wydaje mi się, że jako przyczyna mojej śmierci w grę może wchodzić tylko 
zjawisko zwane powszechnie starczym osłabieniem [3].

Jako potwierdzenie swego nieskazitelnego zdrowia Schreber uważał brak kataru, który zwykł mu towarzyszyć każdej zimy. Dla czytającego pamiętniki może wydawać się argumentem mało przekonującym, ale dla Schrebera był wystarczający:

Jako drobny dowód prawdziwości mego założenia, że stałem się, że tak powiem, nienaruszalny, chcę przytoczyć fakt, iż podczas gdy za moich zdrowych dni każdej zimy zwykt mnie byt nawiedzać trwajacy wiele dni silny katar, przez sześć lat mego pobytu tutaj (w zakładzie leczniczym w Sonnenstein - W.L.) prawie nigdy nie miałem prawdziwego kataru. Gdyby teraz chciały się wytworzyć w naturalny sposób kataralne zapalenia śluzówki nosa - na czym przecież chyba polega istota kataru - to promienie natychmiast napłynęłyby $w$ takiej ilości do chorej części ciała, że katar zostałby stłumiony już w zarodku[3].

Zmiany dotyczące żołądka nie były jedynymi, które Schreber zauważył w swoim ciele. Wielokrotnie doznawał urojeń skrętu kiszek oraz zmian w obrębie przełyku i jelit. W trakcie posiłków zdarzało się, że zjadał własną krtań, łamał sobie zęby i gryzł język. Dodatkowo wąsy wsuwały mu się do ust:

Z innych wewnętrznych organów chcę jeszcze tylko wspomnieć przełyk i jelita, które były przerywane i znikały wielokrotnie, następnie krtań, którq̨ więcej niż raz zjadłem częściowo z posiłkami...[3].

Moje zęby były $w$ ciagłym niebezpieczeństwie; często zdarzało się też, że niektóre z nich łamały się za sprawa cudów. Podczas jedzenia aplikowano mi często cuda gryzienia języka. Włosy wąsów prawie regularnie wsuwano mi podczas positków do ust tak, że już chodźby z tego powodu musiałem się zdecydować w sierpniu 1896 na ich zgolenie[3].

Jego powrózek nasienny był poddawany bolesnym cudom, głównie ze względu na pojawiające się w jego ciele odczucia rozkoszy. Schreber mówił o cudzie, który określał „gniciem podbrzusza”. Był on powodowany przez duszę v.W. (D.P. Schreber w pamiętnikach nie rozwija tych inicjałów. Odnoszą się one najprawdopodobniej do prowadzącego go w Sonnenstein dr. Webera). Dusza ta wprowadzała do jego brzucha substancje gnilne powodujące gnicie podbrzusza. Schreber odczuwał przy tym, że będzie musiał zgnić za życia, a dodatkowo towarzyszył temu odór zgnilizny z ust chorego. Proces gnicia był cofany przez boskie promienie, które wchodziły w jelita i wysysały zgniliznę.

Schreber najbardziej bał się cudów dotyczących jego umysłu:

Najgroźniejsze wydawały się mi samemu te cuda, które w jakikolwiek sposób były skierowane przeciwko rozumowi. W pierwszym rzędzie chodziło przy tym o głowę; $w$ drugiej linii w grę wchodził podczas pewnego (chyba trwajacego kilka tygodni) okresu mniej więcej jesienia 1894 także rdzeń kręgowy, który wówczas uważany był obok głowy za siedzibę rozumu[3].

Schreber twierdził, że jego rdzeń kręgowy był osuszany przez tzw. „małych ludzi”, których włożono mu w stopy. Dwóch z nich rozpoznał i nazwał z imienia i nazwiska. Byli to „mały Flechsig” i „mały v.W.”. Pamiętnikarz twierdzi, że słyszał ich głosy, kiedy ci ze sobą rozmawiali. Osuszanie rdzenia kręgowego powodowało, że w trakcie spacerów po ogrodzie rdzeń kręgowy wychodził mu przez usta w postaci małych chmurek. Wywoływało to u chorego silny lęk związany z poczuciem ulatniania się rozumu. Osuszanie nie było jedynym działaniem na nerwy Schrebera. Ten twierdził bowiem, że wielokrotnie doświadczał jak starano się wyciągać mu nerwy z głowy by przenieść je do osoby śpiącej w pokoju obok. Tym działaniom towarzyszyło uczucie napięcia w głowie. Wyciągane nerwy były na tyle silne, że wracały na powrót do głowy chorego. Na głowę Schrebera działały także ciągi promieni: „zjawisko trudne do opisania, z którego mogę opisać tylko działanie, że moja czaszka była przez nie w często powtarzających się razach jakby piłowana w różnych kierunkach"[3].

Chory odczuwał, że pokrywa jego czaszki zwęziła się, ponieważ kość, z której jest zbudowana częściowo rozsypuje się przez działanie promieni, jednak w trakcie snu czaszka scalała się na nowo. Chory pisze, jakoby jego nerwy wielokrotnie próbowano pokryć jakąś szkodliwą substancją: „Jeden z używanych wówczas środków nosił nazwę «trucizny intoksykacyjnej»"[3]. Chory przywołuje wspomnienie, że w trakcie picia kawy płyn został poprzez cud pobrany z jego wnętrza i przeniesiony na nerwy w jego głowie, co miało utrudniać mu myślenie.

Obok układu nerwowego „działaniom cudów” poddany był także układ mięśniowy i kostny. Mięśnie Schrebera miały momentami zupełnie zanikać i następnie odradzać się. Cuda na mięśniach miały utrudniać poruszanie się i wykonywanie wszelkich czynności. Próby paraliżu palców utrudniały grę na fortepianie i pisanie, wywołany cudem ból w rzepce kolanowej utrudniał spacery. Trudności w grze na fortepianie miały wynikać nie tylko z paraliżu jego palców ale również ze zmian w kierunku patrzenia aby chory nie mógł odczytywać nut z partytury. Cuda zdaniem chorego kierowały palce na złe klawisze. Tempo gry przyspieszało w wyniku kontroli cudów nad mięśniami jego palców. Cuda były odpowiedzialne również za pękanie strun $\mathrm{w}$ fortepianie.

Schreber nie mógł często także czytać ani pisać. W momencie kiedy rozpoczynał te czynności nachodził go silny ból głowy.

Cuda działały także na ośrodki zmysłów i kontrolowały mięśnie zamykające i otwierające powieki oraz miały wpływ na postrzeganie:

Oczy były ważne od dawien dawna, gdyż promienie, które same $w$ sobie wyposażone sq $w$ niszczaca siłę, 
po zobaczeniu czegoś traca swa ostrość w stosunkowo krótkim czasie i umieraja $w$ moim ciele. Przedmiotem widzenia moga być albo wrażenia wzrokowe (oczne), które promienie odbierają za pośrednictwem moich oczu, gdy te sq otwarte, albo częściowo obrazy, które przy użyciu ludzkiej wyobraźni mogę wywoływać dowolnie na mym wewnętrznym systemie nerwowym, tak że staja się one $w$ pewnym stopniu widoczne dla promieni[3].

Promieniom, które działały na wzrok Schrebera towarzyszyły głosy, które przemawiały w „języku podstawowym” inaczej „języku dusz”. One prześladowały Schrebera i kontrolowały procesy otwierania i zamykaniu oczu:

...bardzo wcześnie próbowano zamykać mi oczy wbrew mojej woli, właśnie po to by mnie pozbawić wrażeń wzrokowych i zachować niszczq̨cq ostrość promieni (...). Zjawisko to da się zaobserwować u mnie prawie $w$ każdym dowolnym momencie; kto zechce sobie zadać trud uważnego patrzenia, dostrzeże, że moje powieki, nawet podczas rozmowy $z$ innymi ludźmi, nagle opadaja lub zamykaja się, co w naturalnych warunkach nie zdarza się u każdego człowieka[3].

Schreber pisze, że wjego oczachi ustach znajdowała się dusza Flechsiga oraz v.W. Dzięki Bożej wszechmocy te dusze zostały częściowo wypędzone z głowy Schrebera. Dusza v.W. zabierała Schreberowi myśli, a gdy usadowiła się w jego oczach doznawała tych samych wrażeń wzrokowych co on, tzn. wyglądała przez jego oczy, w sytuacji gdy szukał w swoim otoczeniu jakiegoś przedmiotu. Obecność duszy v.W. w oczach skutkowała zmianą ich wyglądu. Miały one „zaszklony” wyraz, a w gałkach ocznych uwidaczniała się wodnista masa.

Obok prześladowczego działania promieni i dusz na oczy chorego, Schreber opisuje również działanie pozytywne. Chory bowiem mógł patrzeć dzięki promieniom wprost na słońce bez odczucia oślepienia. Miał omamy wzrokowe, twierdził bowiem, że w trakcie spacerów po ogrodzie widział na niebie dwa słońca jednocześnie[3]. Uczucie fizycznego zadowolenia nachodziło ciało Schrebera w wyniku mocno rozwiniętej „rozkoszy duszy”. Niezwykle silna była ona w momentach, kiedy sędzia leżał w łóżku i wyobrażał sobie zmysłową przyjemność zbliżoną do tej, jaką odczuwa kobieta podczas stosunku seksualnego. Obok uczucia fizycznej przyjemności występowały u chorego odczucia bólu. Były to bóle ud i łydek, paraliże, lumbago i bóle zębów. Do odczuć bólowych dochodziło jeszcze silne odczucie głodu.

Chory przez cały czas czuł, żena jego ciało oddziałują nerwy boskie i ludzkie. Dusze i ich nerwy przybierały postać malutkich ludzi wielkości kilku milimetrów. Poruszały się one we wnętrzu oraz na powierzchni jego ciała. Zajmowały się zamykaniem i otwieraniem jego oczu: „stały nad oczami w brwiach i ciągnęły stąd powieki cienkimi jak pajęczyna nićmi w zależności od nastroju w dół i w górę” [3]. Ci sami „mali ludzie” przebywali na jego głowie, gdzie nazywani byli w języku dusz „małymi diabłami”. Dokonywali oni cudów zniszczeń. Zdarzało się, że ci „mali ludzie” zjadali razem z chorym posiłki przez co byli bardziej ospali i mniej dla chorego szkodliwi. „Mali ludzie” dokonywali na ciele Schrebera cudu o nazwie „maszyna ściskania głowy”. Był to obok zwężenia piersi najdotkliwszy cud jakiemu ciało chorego było poddane. Cud „maszyna ściskania głowy” polegał na tym, że wskutek działania promieni od wewnątrz powstawała w czaszce głęboka szczelina. Po obu stronach tej szczeliny znajdowały się „małe diabły”, które przy pomocy urządzenia przypominającego gwintownicę ściskały jego głowę tak, że czaszka wydłużała się i przybierała kształt gruszki. Działaniu temu towarzyszył silny ból. Cudowi temu chory poddawany był przez kilkanaście miesięcy. Na ogół, jak w przypadku większości cudów, ich niszczycielskie działanie było cofane przy udziale boskich promieni.

Innym cudem dziejącym się w głowie Schrebera był cud, który w języku podstawowym głosy określiły jako „Bicz v.W.". Działanie tego cudu polegało na wniknięciu do czaszki chorego niewielkiej części duszy v.W., która wymachiwała w jej wnętrzu małym biczem. Działanie to powodowało duże zniszczenia oraz dotkliwy ból. Obok kości głowy działaniu cudów były poddane również kości stóp. W pięcie Schrebera pojawić się miała bolesna próchnica. Ponadto natrętne myśli Schrebera, które odbierał jako głosy, zakazywały mu myślenia o własnym ciele oraz jedzenia:

postanowiłem zakończyć swoje życie śmierciq głodowa i odmawiałem przyjmowania wszelkich potraw, tym bardziej, że wewnętrzne głosy ciagle mówiły mi, iż właściwie moim obowiązkiem jest umrzeć śmierciq głodowa i w ten sposób niejako oddać się Bogu w ofierze, iż każdy spożyty posiłek, którego moje ciało pragnęło, jest niegodną słabością[3].

Nerwy, które poprzez działanie boskich cudów wprawiane są w drgania, odpowiadają zdaniem chorego, za używanie przez niego poszczególnych słów. One to bowiem sterują działaniem jego narządów mowy, pracą warg, języka i zębów i wprawiają te narządy w ruch.

Schreber wielokrotnie myślał o samobójstwie i podejmował próby odebrania sobie życia. Pierwsza nastąpiła zaraz po przyjęciu Schrebera do szpitala w Lipsku. Po przyjęciu do szpitala Prof. Flechsing postawił diagnozę, że choroba Schrebera została wywołana czynnikiem somatycznym, a mianowicie zatruciem bromkiem potasu. Chory nie zgodził się z tą diagnozą, jako że jego choroby nie mogło spowodować zatrucie, ponieważ dzięki działalności boskich promieni o jakimkolwiek zatruciu jego zdaniem nie może być mowy:

$W$ niezliczonych razach doświadczyłem na własnym ciele i doświadczam także i teraz dzień w dzień, że Bóg jest $n p$. w stanie usunać z ludzkiego ciała poprzez wysyłanie 
kilku czystych promieni każdy zarodek choroby[3].

Głównym objawem $\mathrm{z}$ jakim Schreber trafił do kliniki była bezsenność. Prof. Flechsig zaraz po przyjęciu zastosował terapię polegającą na podaniu hydratu chloralu, dzięki któremu Schreber miał zasnąć. Leki jednak nie zadziałały zgodnie z przewidywaniami. Chory wstał z łóżka w silnym stanie lękowym i chciał udusić się przy pomocy ręcznika. W próbie samobójczej przeszkodziła jego żona. Myśli samobójcze jednak nie opuściły chorego. Czwartej lub piątej nocy po przyjęciu do kliniki Schreber wszczął bójkę z pielęgniarzami w sali bilardowej. Dwóch pielęgniarzy obezwładniło go i przetransportowało do izolatki. Tam Schreber podjął kolejną nieudaną próbę samobójczą próbował powiesić się na prześcieradle. Do popełnienia samobójstwa namawiały go mówiące do niego głosy. Chory obsesyjnie wyobrażał sobie, że topi się w trakcie kąpieli. Realizując te wyobrażenia, kilkakrotnie próbował się utopić:

...każda kapiel, która brałem, była związana z obrazami utopienia się. Mówiono - w języku nerwów $o$ „kąpielach oczyszczajacych” i o „świętych kapielach”, te ostatnie miały właśnie na celu danie mi sposobności do utopienia się; wchodziłem do prawie każdej kapieli opanowany wewnętrznym strachem, że właśnie ta kapiel ma służyć zakończeniu mojego życia. Wewnętrzne głosy (...) przemawiały do mnie $w$ tym właśnie kontekście i szydziły ze mnie, że brakuje mi do tego męskiej odwagi; dlatego też wielokrotnie podejmowałem próbę zanurzenia głowy pod wodę, przy czym strażnicy $w$ niektórych przypadkach trzymali me stopy nad powierzchniq wody, sprzyjali więc pozornie swym zachowaniem mym samobójczym zamiarom, wielokrotnie też zanurzali ma głowę, potem jednak, przy towarzyszeniu grubiańskich dowcipów, zmuszali mnie do wynurzenia się i wreszcie do wyjścia z wody[3].

W czasie, kiedy Schreber przebywał w Lipsku, utrzymywał stały kontakt z prof. Flechsigiem przy pomocy „połączenia nerwów”. W swoich urojeniach prosił prof. Flechsiga o cyjanek potasu lub strychninę (nazywanych w „języku dusz” kroplami „soku-trucizny”) aby się otruć. Schreber twierdzi, że w tych kontaktach prof. Flechsig był $\mathrm{mu} \mathrm{w}$ pełni przychylny i robił choremu nadzieję na swą zgodę:

...podczas trwających godziny rozmów w połączeniu nerwowym uzależniał podanie mi trucizny zawsze $w$ obłudny sposób od pewnych gwarancji, czy ja tę truciznę, o ile zostanie mi ona podana, naprawdę bym wypił itd. Kiedy zaś profesor Flechsig przychodził do mnie podczas lekarskich wizyt jako człowiek, twierdził oczywiście, że nic o takich rzeczach nie wie[3].

Schreberowi w owym czasie obok natrętnych myśli samobójczych towarzyszyło przeświadczenie, że zostanie pogrzebany żywcem. Ponadto w trakcie podróży z kliniki w Lipsku do zakładu w Lindenhof, chory wielokrotnie myślał o rzuceniu się pod pociąg. Obok myśli samobójczych i prześladowczych Schreberowi towarzyszyły także urojenia wielkościowe. W głowie Schrebera przebywały dusze zmarłych, które "język podstawowy” (służący do porozumiewa się Schrebera z Bogiem i duszami) nazywał „małymi ludźmi”. „Mali ludzie” pochodzący z innych planet i gwiazd w ciągu jednej nocy potrafili tysiącami zjawiać się na głowie chorego. Opowiadali mu oni historie mówiące o procesach niszczących planety. Pacjent opisał swoje przeżycia, które można określić jako objawy derealizacji. Chory widzi w innych pacjentach, prof. Flechsingu, personelu kliniki i swojej żonie „nie ludzką istotę, lecz wyczarowaną ludzką postać na wzór «pobieżnie wytworzonych ludzi»”.

Zaburzeniu ulega postrzeganie przez chorego czasu i przestrzeni. Czas wyraźnie ulega rozciągnięciu, chory czuje, że noce trwają setki lat. Klinika w jego opinii została przeniesiona na inna planetę:

Rozważałem różne możliwości, takie jak ta, czy cały zakład Flechsiga albo i miasto Lipsk wraz z zakładem nie zostały „wyjęte” z Ziemi i przeniesione na jakieś inne ciało niebieskie - możliwości, które sugerowały mi czasem rozmawiające ze mna głosy pytaniami, jak na przykład czy Lipsk jeszcze stoi[3].

Chory miał objawy depersonalizacji. Głosy informowały go o istnieniu w przeszłości innego Daniela Paula Schrebera, który miał być bardziej inteligentny. Sam chory stwierdził, że w jego rodzinie nigdy nie było innego Daniela Paula Schrebera, więc uznał, że tym Danielem Paulem Schreberem, o którym mówią głosy jest on sam, tylko że z czasu, „kiedy był w pełnym posiadaniu swoich nerwów", tzn. przed działaniem wpływu boskich promieni. Myśli urojeniowe i głosy ujawniają się $\mathrm{w}$ występującym $\mathrm{u}$ chorego poczuciu mnogości, tzn. chory odczuwa, że w jego głowie jest wiele umysłów:

...będace ze mnq $w$ kontakcie nerwowym dusze rozmawiały o wielości głów (tzn. kilku tożsamościach $w$ tej samej czaszce), na którq się u mnie natknęły i przerażone odskakiwały, mówiąc coś w rodzaju: „Na litość boska, to przecież człowiek o wielu głowach"[3].

Schreber miał wizję, że odbył podróż w głąb Ziemi oraz przez ery jej rozwoju. W wyniku urojeń zatracił poczucie tu i teraz. Wystąpiło u chorego zaburzenie relacji czasowo-przestrzennych. Patologia porządku czasowoprzestrzennego jest zdaniem Antoniego Kępińskiego jednym z głównych elementów struktury świata schizofrenicznego[4]. Schreber twierdził, że jego ciało, ulegając „odmężczyźnieniu”, wypełniło się żeńskimi nerwami rozkoszy, przez co wzmogła się siła przyciągania promieni. $\mathrm{Z}$ tego powodu wielokrotnie wkładano mu do głowy skorpiony oraz podobne do raka lub pająka stworzenia, które miały dokonać w jego głowie zniszczeń:

Miały one charakter dusz, były więc istotami mówiącymi; w zależności od miejsca, z którego pochodziły, rozróżniano skorpiony „aryjskie” $i$ „katolickie”; te pierwsze 
były nieco większe i mocniej zbudowane. Skorpiony te wychodziły jednak regularnie z mojej głowy, nie uczyniwszy mi żadnej szkody, po tym jak stwierdziły czystość moich nerwów i świętość moich przekonań[3]. dusze jezuitów:

Dręczące działania na ciało chorego podejmowały

„Jezuici”, czyli chyba dusze zmarłych jezuitów, po wielokroć starali się włożyć do mej głowy inny „nerw przeznaczenia", przez który miało zostać zmienione moje poczucie tożsamości; wewnętrzne ścianki mojej czaszki wyłożono innq „membraną mózgowa”, by zmazać wspomnienia o moim własnym „ja”. Wszystko bez jakiegokolwiek trwałego sukcesu. Próbowano wreszcie zaczernić moje nerwy, wczarowując $w$ moje ciało zaczernione nerwy innych (zmarłych) ludzi, prawdopodobnie zakładając, że czerń (nieczystość) tych nerwów udzieli się moim własnym nerwom[3].

W ciele Schrebera nie znajdowały się tylko i wyłącznie istoty, które chciały go zniszczyć i utrudnić mu życie, ale także boskie promienie, które ratowały go przed śmiercią.

Trwały związek Boga z nerwami chorego i działające na niego cuda miały doprowadzić do zagłady całego ziemskiego stworzenia. Schreber poprzez łączność z boskimi promieniami miał ulec „odmężczyźnieniu”. Jego zdaniem taki los musi spotkać każdego obcującego z boskimi promieniami:

Ma to zwiqzek po części z naturq boskich nerwów, dzięki której szczęśliwość jest, jeśli już nawet nie wyłącznie, to przynajmniej jednocześnie doczuwanq rozkosza $w$ dużym natężeniu (...), z drugiej zaś strony z jak się zdaje leżącym u podstaw porządku świata planem, jaki pozwoli w przypadku światowych katastrof, które uczyniq koniecznym unicestwienie ludzkości na jakimś z ciał niebieskich - in specie zamierzonego lub nie, odnowić ludzki gatunek[3].

Schreber twierdzi, że na Ziemi w odróżnieniu od innych planet nie doszło jeszcze do zagłady ludzkości, ponieważ „mieszkańcy naszej Ziemi odznaczają się jeszcze stosunkowo większą etyczną czystością." [3].

Schreber wprost popierał teorię katastrof Georgesa Cuviera. Łączył z nią swoje wyobrażenia na temat własnego losu. Uważał, że po światowej katastrofie zachowany zostanie jeden człowiek, moralnie najporządniejszy, którego rozmawiające z nim głosy nazwały „Żydem Wiecznym Tułaczem". Człowiek ten - Schreber uważa, że jest nim on sam - zostanie przeobrażony w kobietę, aby mógł narodzić nowe pokolenia, które zaludnią śwat. Tym urojeniom wielkościowym, związanym z „odmężczyźnieniem”, stale towarzyszyły obsesyjne myśli prześladowcze. Schrebera nie opuszczało wyobrażenie, że jego kobiece ciało zostanie seksualnie wykorzystane a następnie porzucone i pozostawione do zgnicia. Tym myślom towarzyszyły zdarzenia, które według chorego, potwierdzały zaplanowany na nim gwałt:

...trzymano mnie tygodniami $w$ łóżku, uprzednio odebrawszy mi całe moje ubranie, by - jak sq̨dzę - ułatwić dostęp do mnie lubieżnym doznaniom, które mogły zostać wywoływane przez coraz liczniej wnikające we mnie żeńskie nerwy; stosowano środki (medykamenty), które według mego przekonania służyły temu samemu celowi, i które wzwiq̨zku z tym wzdragałem się przyjmować, a gdystrażnicy wlewali mi je do gardła siła, znów je wypluwałem[3].

Schreber odczuwał, że w jego podbrzuszu zamieszkał „bóg” lub „apostoł”, który był uosobieniem pozyskanych z błogostanu promieni:

Wystapiło tu zjawisko obserwowane przeze mnie także $w$ wielu innych jeszcze przypadkach, że zaprzyjaźnione dusze zawsze ciagnęły raczej w okolice narządów płciowych (do brzucha itd.), gdzie nie szkodziły wiele albo wcale i poza tym nie stanowiły prawie $w$ ogóle żadnej dokuczliwości, podczas gdy dusze nastawione bardziej wrogo zawsze dążyły do głowy, której chciały wyrządzić jakaś szkodę, w szczególności osiedlały się w bardzo dokuczliwy sposób przy lewym uchu[3].

Schreber twierdził, że dusza prof. Flechsiga w postaci dużego kłębu lub zwoju przypominającego watę lub przędzę wniknęła do jego brzucha. Dusza ta była na tyle duża, że Schreber nie był w stanie jej strawić. Zlitowała się ona nad nim i wyszła z jego ciała przez usta na zewnątrz. Schreber utrzymywał, że po tym zdarzeniu brał wielokrotnie całe dusze bądź ich części do ust, pozostawiając w nich odczucie przykrego smaku i zapachu. Oprócz prof. Flechsiga w ciało Schrebera wnikali również inni pacjenci z Sonnenstein, zostawiając w nim część swych ciał jako zgniłą masę. W ciele Schrebera gromadzony był trupi jad oraz substancje gnilne pochodzące z promieni chcących pozbawić go rozumu.

Schreber szukał wyjaśnienia swoich doznań w nauce. Nie był przy tym ignorantem, który odrzucał ówczesną wiedzę medyczną. Był przekonany, że to czego doświadcza nie jest objawem chorej psychiki, lecz doświadczeniem metafizycznym i próbował odnaleźć w badaniach naukowych potwierdzenia swoich tez. Chory, będąc w Lipsku, studiował najnowocześniejszy w owym czasie podręcznik do psychiatrii autorstwa Emila Kräpelina. Analizując psychiatryczną charakterystykę pacjentów psychotycznych, podawał argumenty stające za tym, że jego doświadczenia nie miały nic wspólnego z chorobą psychiczną. Stwierdził, że głosy i omamy wzrokowe, których doświadczał były wynikiem działania „nerwów międzyplanetarnych" a nie objawami choroby. Schreber podkreślał, że Kräpelin kierował się oświeceniowym racjonalizmem przez co nie dostrzegał w opisywanych przez siebie przypadkach działalności sił nadprzyrodzonych. Jako argument, że stosunek do Boga nie jest wynikiem urojeń, Schreber przedstawiał swój przedchorobowy stosunek do 
religii i Boga. Otóż niemiecki sędzia uważał, że skoro przed załamaniem nerwowym nie był osobą wierzącą to nie mógł cierpieć na urojenia na tle religijnym:

(...) złudzenie bycia $w$ kontakcie z Bogiem lub $z$ duszami zmarłych może powstać jedynie u takich ludzi, którzy do stanu nerwowego podniecenia nerwów wnieśli już stabilnq wiarę w Boga i nieśmiertelność duszy. W moim przypadku (...) tak jednak nie było[3].

Myśl,że doświadczałboskich cudów zupełnie wypierała w nim świadomość paranoi. Dopuszczał do siebie, że jest tylko nerwowo chory, a jego główna dolegliwość to brak snu. Schrebera nie opuszczało przekonanie, że poczucie ciepła bądź zimna wynikają z działających na jego ciało cudów:

...w przypadku cudu zimna krew wypierana jest $z$ członków, przez co powstaje subiektywne uczucie zimna, zaś w przypadku cudu goraca dzieje się odwrotnie, krew jest pompowana do twarzy i do głowy, które ogólnie lepiej czułyby się w chłodniejszych warunkach[3].

Aby poczuć ulgę chory zaczął poddawać swoje ciało ochłodzeniu:

...sam byłem bardzo często zmuszony szukać chłodu i goraca. Zwłaszcza w pierwszych latach mojego pobytu $w$ tutejszym zakładzie (tj. w Sonnenstein - W.L.), gdy rozkosz duszy jeszcze nie osiagnęła tego natężenia, jaki posiada teraz, był to częstokroć konieczny środek, by odciagnać promienie do marznących części ciała, w szczególności rąk i stóp, $i$ w ten sposób ustrzec głowę przed zamierzonymi szkodliwymi działaniami. Często zdawało się, że w tym celu zima trzymałem przez kilka minut dłonie przy oblodzonych drzewach albo obejmowałem nimi śniegowe kule tak długo, $a \dot{z}$, mi prawie skostniały [3].

Chory w celu wywołania ochłodzenia swojego ciała oprócz dotykania zimnych przedmiotów wystawiał przez kraty w oknie gołe stopy, aby schłodzić je na deszczu. Zdarzało się, że zażywając kąpieli brał prysznic używając tylko zimnej wody. Tego typu działania miały na celu odwiedzenie promieni od głowy chorego. Chory uważał, że dzięki ochłodzeniu stał się zupełnie zdrowy i odporny na wpływy wszelkich groźnych cudownych zjawisk, jakie dotyczyły jego głowy i innych części ciała.

Autor pamiętników nie pomija $\mathrm{w}$ nich swoich problemów z wypróżnianiem. Twierdził on, że tak jak wszystkie inne procesy w jego ciele również wypróżnianie regulowane jest przez działanie cudów. Proces defekacji zdaniem chorego powodował zniszczenie rozumu poprzez wycofywanie się boskich promieni. Schreber, opisując problemy z wypróżnianiem, mówił o utrudnieniach ze strony innych ludzi. Utrudnienia te miały polegać na wysyłaniu kogoś z otoczenia chorego do ustępu w momencie, kiedy tego nachodzi potrzeba. Schreber twierdził, że częstotliwość tego zdarzenia wyklucza przypadek. W związku z tym chory zaczął wypróżniać się do wiadra, co za każdym razem wiązało się z niezwykle silnym uczuciem rozkoszy. Chory wyraźnie stwierdził, że proces defekacji sprawia mu przyjemność:

Uwolnienie od presji, jakq wywołuje znajdujący się $w$ jelitach kat, skutkuje bowiem dla nerwów rozkoszy intensywnym uczuciem przyjemności; tak samo rzecz się ma przy oddawaniu moczu. $Z$ tego powodu podczas wypróżniania się i sikania promienie były zawsze i bez jakiegokolwiek wyjątku zjednoczone, i z tego właśnie powodu podejmowane sq stale próby odwoływania cudem, choć najczęściej na próżno, potrzeby wypróżniania lub sikania, gdy tylko zbieram się do tych naturalnych funkcji[3].

Z. Freud porównuje przyjemność z defekacji występującą u Schrebera do zachowań autoerotycznych, składowych seksualności dziecięcej[2].

Na podstawie ekspertyzy sporządzonej w 1899 roku przez lekarza Schrebera, doktora Webera, można wydobyć główne objawy choroby. Są to:

- $\quad$ myśli hipochondryczne (pacjent utrzymywał, że rozmięka mu mózg, a jego ciało jest poranione w wyniku tortur, jest nadgniłym trupem i jest zadżumiony),

- $\quad$ poważna nadwrażliwość na światło i dźwięk (hiperestezja),

- myśli prześladowcze,

- nasilone zaburzenia wzroku i słuchu,

- zaburzenia nastroju,

- urojenia owładnięcia („całe jego ciało poddaje się odrażającym manipulacjom"),

- $\quad$ urojenia wielkościowe (chory utrzymuje, że ma urodzić nową generację ludzi, oraz, że istnieje „święty cel”, który musi wypełnić),

- $\quad$ autyzm (pacjent zupełnie się odizolował, nie nawiązywał kontaktu, nie wykazywał zainteresowania otoczeniem),

- zaprzestanie poruszania się (stupor halucynacyjny),

- halucynacje ,

- myśli samobójcze i próby popełnienia samobójstwa[5].

Schreber opisał doświadczenia, którym poddane było jego ciało w dwu kategoriach. Do pierwszej kategorii należą doświadczenia wynikające $\mathrm{z}$ jego poczucia bycia prześladowanym i stanowią one element jego urojeń prześladowczych. W drugiej realizował się jako osoba wyjątkowai nadzwyczajna, co należy wiązaćz jego urojeniami wielkościowymi. Zmiany w postrzeganiu własnego ciała określane są $w$ psychiatrii mianem dysmorfofobii. Tym zaburzeniom postrzegania towarzyszy silne i stałe poczucie lęku[6]. U Schrebera ten lęk dotyczył wyłącznie wpływów uszkadzających jego ciało związanych z urojeniami prześladowczymi. Dysmorfofobia obserwowana jest jako 
objaw nerwicy, ale występuje najczęściej w psychozach, szczególnie w początkowym okresie schizofrenii[7]. W przypadku Schrebera można mówić o dysmorfognozji, czyli rozpoznawania u siebie zmian zachodzących w ciele[8]. Czasem zaburzenie jest przyczyną dążenia chorego do zmiany wyglądu i tak też było w przypadku Schrebera, kiedy ten zaczął golić zarost na ciele oraz ubierać się w damską garderobę. Poczucie doświadczania zmian ciała Schrebera i stałego nabywania przez nie cech kobiecych mogło wynikać z zaburzeń jego seksualności. Schreber wypierał ze swojej świadomości problem własnej identyfikacji płciowej. Nie można stwierdzić na pewno, że Schreber miał tendencje homoseksualne, ale relacje ze swoich wyobrażeń dotyczące jego samego spółkującego jako kobieta z mężczyzną mogą potwierdzać tę hipotezę. W urojeniach Schrebera mogła pojawić się wizualizacja jego seksualnych pragnień. Wyraźne problemy widentyfikacji płciowej, wypierane z rzutowaniem ich źródła na zewnątrz (typowe dla objawów wytwórczych) nałożyły się na postępujący rozpad osobowości. Zmiany $\mathrm{w}$ ciele stały się elementem odwoławczym do zmian w psychice. Postępująca $\mathrm{w}$ świadomości Schrebera zmiana w kobietę, odzwierciedlana w ciele, jest wskaźnikiem jego zmian wewnętrznych. Proces postępu choroby nie był niczym hamowany, ówczesne formy terapii nie dawały zadowalających rezultatów. Schreber owładnięty przez permanentne stany psychotyczne szukał powodów swoich doświadczeń w czynnikach zewnętrznych.

Zdaniem Z. Freuda, D.P. Schreber cierpiał na manię prześladowczą. Chory miał erotyczną fantazję oddania się prof. Flechsigowi. Osobowość jego, zdaniem twórcy psychoanalizy, oparła się tej fantazji co w efekcie spowodowało stan mani prześladowczej, w którejupragniony stał się prześladowcą, a treść fantazji treścią prześladowania. Wywołało to u Schrebera paranoję (demencję paranoidalną). Freud przyznał, że nie miał bezpośredniej styczności z autorem pamiętników, a jego refleksja naukowa oparta jest wyłącznie na dziele Schrebera. W czasie, kiedy Schreber opublikował pamiętniki nie było jeszcze takiego opisu dotyczącego schizofrenii, który mamy obecnie. Na niedługo przed śmiercią Schrebera, tj. w 1911 roku, pojawił się artykuł Freuda na jego temat. Sam Freud opisał swój pogląd w 1910, także przed ukazaniem się przełomowego tekstu Eugeniusza Bleulera pt. „Dementia praecox lub grupa schizofrenii”, w którym przedstawiona została charakterystyka schizofrenii. W psychiatrii funkcjonował ówcześnie termin Emila Kraepelina „dementia praecox” - czyli otępienie wczesne. Freud w swoim studium o Schreberze nawiązał do dużej zbieżności objawów u Schrebera z opisanym przez Carla Gustawa Junga przypadkiem pacjenta $z$ dementia praecox. Freud szczególnie mocno podkreślił związek paranoi $\mathrm{z}$ dementia praecox, zaznaczając przy tym, że ten drugi termin został wybrany szczególnie niezręcznie. Z powodu tej niezręczności Freud zaproponował termin parafrenia, który miał być nazwą dla dementia praecox i paranoi scalonych w jedną jednostkę nozologiczną. Określenie „parafrenia” nie przyjęło się i zostało wyparte przez zaproponowany przez Bleuler termin „schizofrenie” (E. Bleuler celowo użył liczby mnogiej, ponieważ traktował schizofrenie jako grupę psychoz).

Jeden ze współczesnych psychoanalityków Zvi Lothane skrytykował stwierdzenie Freuda jakoby Schreber był homoseksualistą i paranoikiem. Zdaniem Lothana sędzia cierpiał głównie na depresję, a urojenia i omamy wynikały u niego z podawanych mu opiatów i bromu. Jego zdaniem przetrzymywanie Schrebera było bezprawne. To co Schreber nazywa "morderstwem na duszy” Lothan odczytuje jako pogwałcenie wolności osobistej, która przybrała wymiar prześladowania prawnego przy użyciu środków psychiatrycznych. Lothan twierdzi, że uwadze Freuda umknęło występowanie u sędziego tzw. nerwicy aktualnej, tzn. niezaspokojonego wieloletniego głodu seksualnego, który można zaobserwować np. u więźniów. Myślenie misjonistyczne, którego przejawów w pamiętnikach jest bardzo dużo, zdaniem Lothana nie pochodziło $\mathrm{z}$ paranoi, ale było wynikiem ducha czasów, kiedy bardzo popularne (szczególnie w wyższych sferach, a do takich należał Schreber) były ruchy masońskie (Schreber pisze w pamiętnikach o księciu Adamie Kazimierzu Czartoryskim, jako o jednym z „Żydów Wiecznych Tułaczy”, który na pewno należał do loży masońskiej i brał udział w praktykach okultystycznych).

Jeszcze dziś pamiętniki D.P. Schrebera są powodem wielu dyskusji i wzbudzają duże emocje wśród ich czytelników. Mój artykuł ograniczył się głównie do zaburzeń w postrzeganiu własnego ciała jakie wystąpiły u chorującego na psychozę D.P. Schrebera. Nie przedstawia on charakterystyki wszystkich urojeń, a wyłącznie te, które związane były ze zmianami w ciele chorego. Kreatywność umysłu Schrebera, który został zawładnięty przez chorobę zasługuje na szacunek. Barwność, wielokulturowość i mnogość motywów, które włączył do swych urojeń świadczą o jego dużej wiedzy i inteligencji. Cienka granica pomiędzy rzeczywistością a fantazją została w jego przypadku zatarta. Schreber nie był w stanie dokonać wglądu w swoje przeżycia. Brak krytycyzmu doświadczeń zupełnie go zgubił. Wszystkie próby racjonalizacji spełniały przeciwną do założonej rolę. Przedstawiony w artykule sposób postrzegania ciała przez chorego na schizofrenię Schrebera jest dobrym miernikiem zmian $\mathrm{w}$ jego psychice. Ten życiowy racjonalista $\mathrm{w}$ wyniku choroby nie był w stanie w sobie i swoim otoczeniu odnaleźć elementu, którego charakter czy cechy mogłyby zwracać go ku realnej rzeczywistości. Omnipotencja schizofrenii jest bezwzględna. Nawet we własnym ciele potrafi w chorym wzbudzić wątpliwości. To co wydaje się stałe - ciało, czyli konstrukcja anatomiczna, poprzez chorobę staje się płynne i podlegające zmianom. Domniemane zmiany $w$ ciele 
Schrebera, jak pokazuje ten przegląd, nie były subtelne. Wręcz przeciwnie - były one dramatyczne i zaprzeczały możliwości przeżycia. Jednak $\mathrm{w}$ chorym nie wzbudzało to żadnych wątpliwości, bowiem bezwolnie poddawał się urojeniom. Należy stwierdzić, że to fałszywe przekonania kierowały Schreberem w każdym momencie choroby. I nawet wydawałoby się olbrzymia absurdalność jego doświadczeń i zmian dokonujących się w nim samym nie wystarczała aby wykluczyć jestestwo. Tekst „Pamiętników” pozwala przyjrzeć się procesowi zmian w psychice dokonujących się pod wpływem choroby z rzadko w pełni dostępnej perspektywy. Perspektywy nie obserwatora z zewnątrz, świadka wydarzeń stojącego $\mathrm{z}$ boku, ale perspektywy samego chorego, osoby, która choroby doświadcza. W historii choroby Schrebera dokonała się rzecz niezwykła - jego urojenia z zespołu fałszywych przekonań zostały przez niego w dużym stopniu ucieleśnione. Wszelkie zmiany w stanach afektywnych objawiające się niestabilnością miały olbrzymie odniesienie do cielesności Schrebera. Jego dążność do samounicestwienia (próby samobójcze są częste w schizofrenii) przenikała się z poczuciem nieśmiertelności i wielkiego sensu oraz celowości istnienia. Wszystkie te ambiwalencje odzwierciedlały się w ciele. Jednocześnie funkcjonowały ze sobą w symbiozie silne antagonizmy. Chory poddawał się im bezkrytycznie. Ciało, które aby spełniać swoje zadanie musi być zdrowe, doświadczało w urojeniach Schrebera pełnej degradacji. Jednocześnie było poddawane zniszczeniu i uzdrowieniu. Ciało Schrebera było świętością, która ma ocalić ludzkość przez połączenie z bogiem ale też profanacją, która czerpie przyjemność z gwałtu. To co dla osoby zdrowej stanowi zupełną sprzeczność i co odrzuca wszelki sens dla chorego było czymś zwyczajnym i nie budzącym zdziwienia, z czym godzi się z całą pewnością. Nie ulega wątpliwości, że „Wielkie myśli nerwowo chorego” to dzieło wyjątkowe w skali świata i stanowi wspaniałe studium choroby psychicznej.

\section{Conflict of interest}

The author has declared no conflict of interest

\section{References}

1. Lothane Z. W obronie Paula Schrebera. Neuropsychiatria. Przegląd kliniczny, 2009; 3(3): 4-14.

2. Freud S. Psychoanalityczne uwagi o autobiograficznie opisanym przypadku paranoi (Dementia paranoides) Charakter a erotyka. Warszawa; Wydawnictwo KR: 2009, s. 105-165.

3. Schreber D.P. Pamiętniki nerwowo chorego. Kraków; Libron: 2006.

4. Kępiński A. Schizofrenia, Kraków; Wydawnictwo Literackie: 2001.

5. Lipski W. Obraz obłędu w literaturze - mity i rzeczywistość W: Łoch. E., Wallner G., Flis-Czerniak E. red. Człowiek wobec epidemii chorób zakaźnych od starożytności po czasy współczesne w świetle literatury i medycyny. Lublin; Wyd. UMCS: 2011, s. 309-337.

6. Korzeniowski L., Pużyński S. red. Encyklopedyczny słownik psychiatrii, Warszawa; PZWL: 1986.

7. Bilikiewicz A. Pużyński S. Rybakowski J. Wciórka J. red. Psychiatria t. 2, Psychiatria kliniczna, Wrocław, Urban \& Partner: 2002.

8. Jarema M. Leksykon schizofrenii. Poznań, Termedia Wyd. Med.: 2010.

\section{Corresponding adress}

Wojciech Lipski

Zakład Logopedii i językoznawstwa Stosowanego UMCS, Dom Studenta "Kronos" UMCS, 20-040 Lublin, ul. Sowińskiego 17 (II piętro)

tel. 815375415 (nr wew. 125)

e-mail: wojciech.lipski@poczta.umcs.lublin.pl

Otrzymano:27.02.2018

Zrecenzowano: 22.03.2018

Przyjęto do druku:12.06.2018 